Yeshiva University, Cardozo School of Law

LARC @ Cardozo Law

Articles

Faculty

1995

\title{
The Identity of the Constitutional Subject
}

Michel Rosenfeld

Benjamin N. Cardozo School of Law, mrosnfld@yu.edu

Follow this and additional works at: https://larc.cardozo.yu.edu/faculty-articles

Part of the Law Commons

\section{Recommended Citation}

Michel Rosenfeld, The Identity of the Constitutional Subject, 16 Cardozo Law Review 1049 (1995).

Available at: https://larc.cardozo.yu.edu/faculty-articles/140

This Article is brought to you for free and open access by the Faculty at LARC @ Cardozo Law. It has been accepted for inclusion in Articles by an authorized administrator of LARC @ Cardozo Law. For more information, please contact larc@yu.edu. 


\title{
THE IDENTITY OF THE CONSTITUTIONAL SUBJECT
}

\author{
Michel Rosenfeld*
}

"[J]e pense où je ne suis pas, donc je suis où je ne pense pas."

Jacques Lacan ${ }^{1}$

\section{The Elusive Nature of the Constitutional Subject AND OF CONSTITUTIONAL IDENTITY}

The identity of the constitutional subject is elusive and problematic as uncontroverted foundations are hard to come by in contemporary constitutional regimes. The notion of the constitutional subject is itself ambiguous because it is not clear whether it refers to those subject to the constitution, or to the makers of the constitution, or to the subject matter of the constitution. Moreover, even if the who or what of the constitutional subject were settled, the concept of constitutional identity would still be fraught with difficulties. Not only is constitutional identity likely to change over time, but it is also likely to be immersed in complex and ambiguous relations with other relevant identities; such as, national, ethnic, religious, or cultural identity.

To establish constitutional identity over time it is necessary to weave together the past of the framers, one's own present, and the future of unborn generations. The problem, however, is that the past as much as the future is uncertain and open to conflicting possibilities, thus vastly complicating the task of unearthing threads of continuity. Even if the framers' actual intent were clearly and fully accessible, how much, and in what respects, it ought to be relevant or binding on a particular subsequent generation would remain a matter of dispute. And given that the framers' intent can be gauged at different levels of abstraction, there is always room for reinterpreting and reconstructing one's constitutional identity. ${ }^{2}$

* Professor of Law, Benjamin N. Cardozo School of Law, Yeshiva University. I wish to thank David Gray Carlson for his many helpful and perceptive comments.

1 JACQUES LACAN, ÉCRITS 517 (1966) ("I think where I am not, therefore I am where I do not think.") (my translation).

2 Originalism and its commitment to follow the framers' intent in its most concrete expression does not successfully solve the uncertainty of the constitutional past, notwithstanding its narrow focus. For one thing, it is by no means obvious that it is wise to freeze constitutional identity at the moment of its inception. But even if that were deemed desirable, it would be self-contradictory to the extent that the framers themselves intended to 
At least in written constitutions, constitutional identity is bound to be problematic in terms of the constitution's relation to itself. A written constitutional text is inevitably incomplete and subject to multiple plausible interpretations. It is incomplete not only because it does not cover all subjects that it ought ideally to address, but also because it cannot exhaustively address all conceivable issues arising under the subjects that it does encompass. Moreover, precisely because of the incompleteness of the constitutional text, constitutions must remain open to interpretation; and that, in most cases, means open to conflicting interpretations that appear to be equally defensible. ${ }^{3}$ Thus, for example, one cannot get an adequate picture of the constitutional identity of the United States unless one supplements the constitutional text with the long string of interpretations and elaborations found in two centuries of Supreme Court decisions. ${ }^{4}$ Yet, the legitimacy of this larger picture has been vigorously contested as exemplified by one recent Attorney General's attempt to minimize the importance of Supreme Court decisions in shaping the country's constitutional identity, by placing a wedge between "the Constitution" and "constitutional law." But even the most exalted originalists, textualists, and purists have been unable or unwilling to flatly repudiate the Supreme Court's legacy in their attempts to cleanse constitutional identity of all its excesses and impurities. ${ }^{6}$

Another problem concerning the relationship between the constitution and itself, is that between constitutional amendments

provide an adaptable framework capable of meeting the needs of future generations. See McCulloch v. Maryland, 17 U.S. 316, 415 (1819) ("[A] constitution [is] intended to endure for ages to come, and, consequently, to be adapted to the various crises of human affairs.").

3 It may seem that this problem may be altogether avoided by adhering to what may be referred to as a "minimalist" approach to constitutional interpretation, according to which unless the constitutional text clearly and explicitly grants a right no such right shall be recognized, thus erring if necessary on the side of democracy. Upon reflection, this minimalist approach is no better than an expansionist approach that reads as many rights as possible into the constitutional text. Indeed, the fact that the constitutional text may be general and vague no more justifies denying intended rights than it does granting rights that were not intended.

4 See, e.g., Plessy v. Ferguson, 163 U.S. 537 (1896); Lochner v. New York, 198 U.S. 45 (1905); Brown v. Board of Education, 347 U.S. 483 (1954); Nebbia v. New York, 291 U.S. 502 (1934); Griswold v. Connecticut, 381 U.S. 479 (1965); Roe v. Wade, 410 U.S. 113 (1973).

5 Edwin Messe III, The Law of the Constitution, 61 TuL. L. Rev. 979, 981-82 (1987).

6 See e.g., 14 The Supreme Court of the United States-Hearings and RePORTS ON SUCCESSFUl, aNd UNSUCCESSFUl NOMINATIONS OF SUPREME COURT Justices By the Senate Judiciary Committee 1916-1987: Robert H. Bork 292-96 (Roy M. Mersky \& J. Myron Jacobstein eds., 1990); Henry P. Monaghan, Stare Decisis and Constitutional Adjudication, 88 Colum. L. Rev. 723 (1988). 
and constitutional identity. Given that some constitutions explicitly restrict the scope of legitimate amendments ${ }^{7}$ and others do not, ${ }^{8}$ and that the ease with which a constitution may be amended varies from country to country, ${ }^{9}$ at what point do constitutional amendments threaten to destroy constitutional identity? In extreme cases, such as that of Hungary during the course of its recent transition from socialism to democracy, the amendment process was used to effectuate a complete overhaul of the constitution, ${ }^{10}$ thus negating any identity between the constitution prior to, and subsequent to, amendment. But what about less extreme cases, such as the United States before and after the Civil War amendments? Did the transition from the constitutional acknowledgment of the legality of slavery ${ }^{11}$ to its explicit constitutional ban, undermine or bolster American constitutional identity? ${ }^{12}$

The clash between constitutional identity and other relevant identities, such as, national, ethnic, religious, or cultural identity, is made inevitable by the confrontation between contemporary constitutionalism's inherent pluralism, ${ }^{13}$ and tradition. As Ulrich Preuss aptly observes, constitutional order requires imposing constraints on the spread of a nation's prepolitical communal identity. ${ }^{14}$ Accordingly, in an important sense, constitutional identity runs counter to other relevant identities. For example, in a country

7 This is the case in Germany. See Grundgesetz [Constitution] [GG] art. 79 (F.R.G.).

8 See e.g., U.S. CONST. art. V.

9 Compare U.S. ConsT. art. V (two-thirds of both houses shall propose amendments that must be ratified by three-fourths of the States) with A MAGYAR KOZTARSASAG ALKETMANYA [Constitution] ch. I, § 24(3) (Hung.) (constitutional amendment requires a twothirds majority in Parliament).

10 Since 1989 , every provision in the Hungarian constitution has been changed except for that section which states that Budapest is the capital of Hungary. A MAGYAR KOZTARSASÁG ALKETMANYA ch. XIV, § 74(3).

11 U.S. Const. art. I, $\$ 2$, cl. 3.

12 Compare Thurgood Marshall, II Justice Marshall's Views: Constitution "Defective From the Start," Legal Times, May 11, 1987, at 15 (arguing that the Constitution did not survive the Civil War) with David A.J. Richards, Revolution and Constitutionalism in America, 14 CARDozo L. Rev. 577 (1993) (arguing that the post-Civil War amendments were consistent with the history of American revolutionary constitutionalism).

13 "Constitutionalism makes little sense in the absence of any pluralism. In a completely homogeneous community with a single-minded collective purpose and without a conception of the individual as having any legitimate rights or interests separate from those of the community as a whole, constitutionalism ... would be superfluous." Michel Rosenfeld, 11 Const. Commentary 432, 435 (1994) (reviewing Gary J. Jacobsohn, APPLe of Gold: Constitutionalism IN ISRaEl and the Untred States (1993)).

14 See Ulrich K. Preuss, Constitutional Powermaking for the New Polity: Some Deliberations on the Relations Between Constituent Power and the Constitution, 14 CARdozo L. REv. 639, 651-52, 660 (1993). 
with a strong constitutional commitment to religious pluralism, constitutional identity must not only be distinct from any religious identity, but must also stand as a barrier against national identity becoming subservient to the fundamental tenets of any religion.

Constitutional identity would not be so problematic if it could simply be defined in opposition to the relevant identities mentioned above. Such a negative definition, however, would place constitutional identity at such a high level of abstraction as to render it practically useless. Thus, for example, contemporary constitutional identity is shaped by, among other things, respect for fundamental equality and freedom of expression rights. But severed from all ties and relevant national or cultural identities, these fundamental constitutional rights would remain too amorphous to allow for cogent applications. Indeed, how could one decide, without any reference to national or cultural identity, whether constitutional equality requires equality of outcomes or only equality of opportunity? ${ }^{15}$ Or whether free speech encompasses extremist speech? ${ }^{16}$

Ultimately, constitutional identity is problematic because in addition to remaining opposed to, and distinct from, other relevant identities, it is inevitably forced to incorporate them partially to acquire a sufficiently determinate meaning. Even if constitution makers could scrupulously avoid referring to these other identities in drafting a broadly based constitutional text, traces of the left out identities would undoubtedly creep back into the constitutional corpus, as a by-product of the interpretation and elaboration of constitutional norms. Constitutional interpreters cannot be completely stripped of their national or cultural identity. Accordingly, the key question becomes how constitutional identity can distance itself sufficiently from the relevant identities against which it needs to forge its own image while, at the same time, incorporating enough elements from these identities to remain viable within its own sociopolitical environment.

Based on the preceding observations, constitutional identity emerges as complex, fragmented, partial, and incomplete. In the

15 For an argument suggesting that the United States Supreme Court has favored equality of opportunity at the expense of equality of result consistent with the American ideology, see Michel Rosenfeld, Affirmative Action and Justice: A PhilosophiCAL AND CONSTITUTIONAL, INQUiRY 158-59, 173 (1991).

16 See Frederick Schauer, Free Speech and the Cultural Contingency of Constitutional Categories, 14 CARDozo L. REv. 865, $877-80$ (1993) (contrasting U.S. constitutional protection of neo-Nazi speech with legitimacy of its suppression under the German constitution). 
context of a living constitution, moreover, constitutional identity is the product of a dynamic process that is always open to further elaboration and revision. Similarly, the constitutional subjecthowever defined-seems bound to remain incomplete and susceptible to further definition. Take for example, "We The People," which looms as the constitutional subject in the United States. In the abstract, "We The People" seems to be all encompassing in its seemingly full embrace of both constitution makers and all those to whom the Constitution applies. "We The People" merges together constitution makers and those subject to the Constitution, as well as the governors and the governed, much the same as Jean Jacques Rousseau's social contract is supposed to generate unity out of multiplicity, through adherence to the general will. ${ }^{17}$ Moreover, if "We The People" both formulate the Constitution and willingly submit to its dictates, the subject matter covered by the Constitution would be inherently legitimate as that which the constitutional authors have freely chosen to impose on themselves, and have voluntarily chosen to embrace in their capacity as citizens of a constitutional democracy. ${ }^{18}$ In short, by focusing on "We The People" in the abstract, and by regarding it as an encompassing unity comprising constitution makers and citizens subject to the Constitution, it seems possible to overcome the vexing difficulties raised by the who and what of the constitutional subject.

When approached from a more concrete vantage point, however, the unity of "We The People" becomes shattered. For one thing, the authors of the 1787 American Constitution, a group of propertied White men, ${ }^{19}$ were in no way representative of all those who would be subjected to their constitutional prescriptions. ${ }^{20}$ For

17 "The glue that binds Rousseau's individual to civil society is the general will. Indeed, the general will is that by which the people united as sovereign must govern, and that to which each individual, as a member of the governed, must yield without reservation." Michel Rosenfeld, Contract and Justice: The Relation Between Classical Contract Law and Social Contract Theory, 70 Iowa. L. REv. 769, 868 (1985); see also JEAN JACQues RousSeau, The Social Contract 14-18 (Charles Frankel ed., 1947) (1762).

18 Cf. Jurgen Habermas, Paradigms of Law, in Between Facts and Norms: Con. TRibutions to A Discourse Theory of LAw AND DEMOCRACY (forthcoming 1995) (advocating a proceduralist paradigm of law, according to which law's legitimacy is predicated on establishing an identity between the law's authors and those made subject to its prescriptions).

19 See Charles A. Beard, An Economic Interpretation of the Constitution of THE United States 73-149, 149-51 (1935); Larry G. Simon, The Authority of the Framers of the Constitution: Can Originalist Interpretation Be Justified?, 73 CAL. L. REv. 1482, 1498 \& n.44 (1985).

20 See Bureau of the Census, U.S. Dep't of Com., Historical Statistics of the UNited STATES: Colonial Times To 1970, at 22 (1975) (at the time of the adoption of the 
another, when placed in its proper historic setting, "We The People," far from expressing a genuine unity, actually embodies a stark contradiction. The meaning of "We The People" in the Preamble to the 1787 Constitution cannot be grasped without reference to the proposition that "all men are created equal," which is enshrined in the 1776 American Declaration of Independence. ${ }^{21}$ Based on the fundamental creed that all "men"-meaning all "human beings" - are created equal, moreover, "We The People" should have referred to, at least, all adults permanently residing in the United States in 1787.22 To the extent that the 1787 Constitution condones slavery, ${ }^{23}$ however, "We The People" cannot be fairly said to include the African American slaves then living in the United States. Accordingly, the "We The People" of 1787 is inconsistent with "all men are created equal." Moreover, the exclusion of African Americans from "We The People," negates the possibility of any genuine identity between the authors of the 1787 Constitution-taken in the broadest possible sense as including anyone who may have reasonably been prompted to voluntarily acquiesce to the terms of that Constitution-and all those who were subjected to the weight of its prescriptions. Indeed, neither history nor logic justifies inclusion of African Americans in "We The People," as it existed prior to the American Civil War. ${ }^{24}$

This initial glance into constitutional identity and the constitutional subject reveals that it is much easier to determine what they are not, rather than what they are. Building upon this insight, I explore the thesis that it is ultimately preferable and more accurate to regard the constitutional subject as an absence rather than a presence. In other words, the very question of the constitutional subject is prompted because we find a lack in the place where we seek an ultimate source of legitimacy and authority for the constitutional order. Furthermore, the constitutional subject must be

Constitution, approximately $50 \%$ of the population was female and approximately $24 \%$ was African American).

21 For an enlightening historical and theoretical discussion of these issues, see Richards, supra note 12.

22 Even if one chooses to read "all men are created equal" in the more narrow, sexist sense, "We The People" would still have had to include all adult males permanently residing in the United States.

23 See U.S. ConsT. art. I, §§ 2, 9.

24 That African Americans had to suffer from constitutional prescriptions of which they could in no way be considered the authors is vividly illustrated by the infamous decision of Dred Scott v. Sanford, 60 U.S. (19 How.) 393 (1857) (emancipation of slave pursuant to federal law held unconstitutional as it violated the former slave owner's property rights under the Fifth Amendment's Due Process Clause). 
considered as a lack or an absence in at least two different senses: First, the absence of the constitutional subject does not negate its indispensability, thus necessitating its reconstruction; and, second, the constitutional subject always involves a lack because it is inherently incomplete, and hence always open to a necessary but impossible quest for completion. Accordingly, the constitutional subject is in constant need of reconstruction, but no such reconstruction can ever become definitive or complete. Consistent with this thesis, moreover, constitutional identity must be constructed in opposition to other identities, to the extent that it cannot survive unless it remains distinct from the latter. On the other hand, constitutional identity cannot simply dispose with these other identities, and must therefore strive to incorporate and transform some elements borrowed from such other identities. In short, the identity of the constitutional subject is only susceptible of partial determination through a process of reconstruction oriented towards striking an equilibrium between assimilation and rejection of the other relevant identities discussed above.

The thesis that the identity of the constitutional subject originates in a lack or absence, bears certain strong affinities with Sigmund Freud's and Jacques Lacan's psychoanalytic theory of the subject and with Georg Hegel's philosophical theory of the subject. I shall, accordingly, draw on certain insights developed by these theories to elaborate some of the key features of my thesis. In particular, in Part II, I refer to these theories to determine the position of the constitutional subject and to justify the need for reconstruction. In Part III, having concluded that the constitutional subject is the subject of constitutional discourse, I argue that the principal tools of reconstruction are negation, metaphor, and metonymythe first being central to Hegel's philosophy, and all three to Freud's and Lacan's theories. Finally, in Part IV, based on the dialectics of reconstruction as elaborated in Part III, I explore the potential and the limitations of the constitutional subject in its struggle to strike an equilibrium in an ever changing sociopolitical landscape. 
II. The Position of the Constitutional Subject ANd the NEED FOR RECONSTRUCTION

\section{A. The Constitutional Subject and the Clash Between Self and Other}

The question of the subject arises out of the need to confront the other. ${ }^{25}$ So long as human interaction is not perceived as involving a cleavage between self and other, neither the existence nor the place of the subject is likely to raise any significant problems. $^{26}$ From the perspective of modern constitutionalism, moreover, the premodern political order could avoid dwelling upon the opposition between self and other, to the extent that it could hold together a unified vision shaped by commonly shared and mutually supporting religious, ethical, political, and legal norms. ${ }^{27}$ Modern constitutionalism, on the other hand, cannot avoid the confrontation between self and other as a consequence of its inherent pluralism. On one level, the pluralist constitutional self encounters as the other the tradition that held together the premodern sociopolitical order. This other can be referred to as the "external other." On another level, constitutional pluralism requires that a group constituting a collective self recognize similarly positioned groups as other selves, and/or that each individual self treat the remaining individuals as other selves. In contrast to the external other, this latter other dwelling within the constitutional polity can be called the "internal other." 28

As retraced in Hegel's Phenomenology, the confrontation between self and other emerges out of the split between subject and object. ${ }^{29}$ Animated by desire, the subject pursues objects, but these objects can only assuage desire momentarily, for once they are incorporated, desire inevitably turns its quest elsewhere. Eventually, the subject realizes that desire cannot be satisfied by objects. Rather, in order to perpetuate itself, it must turn to other subjects who can over time satisfy its desire. Hence, the desire of the sub-

25 See Georg W.F. Hegel, Phenomenology of Spirit 191 175-96, at 109-19 (Arnold V. Miller trans., Oxford Univ. Press 1979) (5th ed. 1952); LACAN, supra note 1, at 655-56.

26 See Sigmund Freud, Civilization and its Discontents 13-14 (James Strachey ed. \& trans., W.W. Norton \& Co. 1961) (1930).

27 This is not meant to imply that the premodern world did not experience its fair share of dissent and internal conflict, but rather that it was more bent on suppressing or subordinating dissenters than on tolerating or accommodating those who did not subscribe to the officially endorsed normative value system.

28 For further discussion of the relationship between internal and external other, see infra part IV.

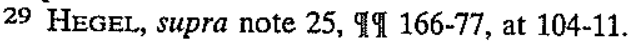


ject prompts the self to seek out the other. Similarly, in the context of psychoanalytic theory, the subject seeks fulfillment in objects, but this is impossible, thus prompting a need for adjustment through a process of renunciation. In other words, the ego of psychoanalysis must forgo appropriation of forbidden objects, to aspire to recognition by the other (through internalization of the edicts of the superego). ${ }^{30}$

The foregoing accounts of the relation between subject and object reveal the subject as lacking in at least two different senses. First, to the extent that the subject needs objects, the subject is characterized by a lack in the sense of being incomplete. Second, the as yet unrecognized (by an other) subject is a lack, in the sense of being nothing but the negation of its objects, i.e., its defining characteristic is the subject not being any of the objects of its desire. Accordingly, upon splitting from the object, the subject emerges as awareness of absence and incompleteness. In short, the question of the subject arises upon the subject in question experiencing the pain of absence and unfulfilled completeness.

Upon realizing that the road to fulfillment is not through objects of desire, the self of Hegel's Phenomenology turns to the other for recognition. The identity of the subject thus becomes predicated on recognition by others. But, as Hegel's celebrated account of struggle between the Lord and the Bondsman illustrates, shifting the focus from objects to other subjects does not, of itself, bring about reciprocal recognition among equals. ${ }^{31}$ Instead, the Lord having overcome the fear of death, opts to become the recognized self, whereas the Bondsman constrained by his fear of death, agrees to assume the role of the recognizing self. Accordingly, the Bondsman gives up his own identity to save his life, while the Lord buttresses his self-identity by having the Bondsman execute his commands. Because of the working of the dialectic, however, the Bondsman's work for the Lord leads to a reversal of roles. Indeed, as a consequence of his reliance on the Bondsman's work to satisfy his needs, the Lord becomes dependent on the Bondsman, and the identity of the recognized self becomes subject to being shaped through the labors of the recognizing self. Conversely, through his labor, which he grasps as his own notwithstanding that it is being undertaken pursuant to the Lord's commands, the Bondsman gains a sense of his own identity and of his mastery over his products. In sum, although the Lord seeks to become master of his own identity

30 See Freud, supra note 26 , at $72-73$.

31 See HEGEL, supra note 25, Tा $178-96$, at 111-19. 
and to enslave the Bondsman to secure a faithful reflection of his lordly self-image; in the end, in the terms of Jean Hyppolite, the slave becomes the master of the master, while the master becomes the slave of the slave. ${ }^{32}$

Hegel's insight that the self's attempt to root its identity as subject leads to subjection to the other, is further elaborated by Lacan. ${ }^{33}$ Pursuant to Lacan's analysis, the child's initial grasp of identity as subject involves a twofold process of alienation, or of subjection to the other. ${ }^{34}$ Prompted by his or her failure to fully or successfully merge with the object of his or her desire, the child experiences himself or herself as a lack, and strives to fill this felt void by acquiring an identity as subject-an identity poised to counter the centrifugal movement of unchecked desire driven towards an infinite series of objects that resist satisfactory incorporation. To acquire an identity as a subject, however, the child must leave behind the world of objects and enter into the symbolic order of language. Only through the mediation of language can the child hope to assert his or her identity as a subject. But language and the rules that organize it into a system of communication are imposed on the child from the "outside." Accordingly, language alienates the child by making submission to a symbolic code imposed by others, a prerequisite to acquiring his or her own identity as a subject. ${ }^{35}$

To the alienation produced by the necessary confrontation with language must be added, consistent with Lacan's account, yet another alienating experience along the child's path towards identity as a subject. Indeed, as the child struggles to get his or her bearings in the symbolic universe circumscribed by language, he or she first gains a sense of identity through recognition of his or her name. Because it is the parents who name their child, and because it is others who first address the child by his or her name, however, gaining identity by recognizing a name as one's own is alienating. In other words, the first articulable experience of one's identity as

\footnotetext{
32 See 1 Jean Hyppolite, Genese et Structure de la Phénoménologie de L'EsPrit de Hegel 166 (1946).

33 For a discussion of Hegel's influence on Lacan, see Bertrand OGILVIE, LACAN: LA Formation du Concept de Sujet (1932-1949), at 30-31, 108-09 (3d ed. 1993).

34 See LACAN, supra note 1, at 839-40 ("alienation is the reality of the subject") (my translation).

35 See id. at 655. It may not seem obvious to the adult that the need to rely on language to express one's own identity is alienating. It is not difficult to imagine, however, that it would be alienating and frustrating to have to convey an accurate and comprehensive sense of one's innermost identity in a foreign language which one does not sufficiently dominate.
} 
a subject is alienating, inasmuch as it consists in identifying oneself with a name chosen by another, and in acquiescing to being identified as a symbol in the discourse of the other. ${ }^{36}$

Although Hegel and Lacan present us with different narratives, their conclusions concerning initial attempts to establish the identity of the subject are remarkably similar. In both cases, the subject emerges in its own right as a consequence of a lack, and requires mediation in its search for identity. In both cases, moreover, the subject's initial thrust towards identity proves alienating as it results in an unexpected subjection of the self to the other.

Upon first impression, the constitutional subject may seem fundamentally different from its Hegelian and Lacanian counterparts. Particularly, if it emerges in the aftermath of a revolution, the constitutional subject - at least in its initial stage - may seem in control, having smashed the antirevolutionary other, and not yet having to confront directly the other of future generations. As the holder of constituent power, the constitutional subject appears to be in a position to impose its will, or in Ulrich Preuss's words, to "create a political world ex nihilo." 37 Hence, far from emerging as a lack or as alienated, the constitutional subject seemingly undertakes to fashion a new political order in its own image, from a position of absolute mastery, perched high above the smoldering remnants of traditions laid to waste by the revolution.

Upon more exacting scrutiny, however, the constitutional subject's quasi-divine appearance begins to unravel. This is not only because as the generation of constitution makers recedes further into the past, we become increasingly the prisoners of our constitutional heritage. Indeed, even if we focus exclusively on the generation of successful revolutionaries who have become constitution makers, in the realm of human affairs there is ultimately no such thing as creation ex nihilo. ${ }^{38}$ Not even the radical rupture of violent revolution makes for complete differentiation between prerevolutionary and postrevolutionary political orders. In many cases, prerevolutionary traditions are not completely eradicated, but transformed and selectively incorporated into the new order fashioned by the constitutional subject. ${ }^{39}$ To a significant degree,

36 See id. at 298-300, 655.

37 Preuss, supra note 14 , at 639.

38 See id.

39 See, e.g., U.S. CoNST, art I, $\S 9$, cl. 1 (slave trade practices established prior to the Constitution not subject to Congressional abolition for more than twenty years); U.S. ConsT. amend. VII (right to a jury trial in certain types of cases established prior to the Constitution given continued protection by the Constitution). 
therefore, the past sought to be countered determines the content of constitutional provisions elaborated by revolutionary constitution makers. ${ }^{40}$

Not only the past, but also the present and the future, are bound to constrain revolutionary constitution makers; thus, belying the notion that a genuine constitutional self may impose its will by eliminating or disregarding the other. Unrestrained imposition of revolutionary will leads not to constitutionalism, but to the reign of terror. As demonstrated by the experience of the French Revolution, untempered revolutionary zeal merely succeeds in replacing a repressive tradition, which disregards the other, with an equally rigid and repressive order predicated on exclusion rather than inclusion. ${ }^{41}$

Inasmuch as constitutionalism is wedded to pluralism, it must take the other into proper account, which means that constitution makers must forge an identity that transcends the bounds of their own subjectivity. Accordingly, from the standpoint of the constitution makers, the identity of the constitutional subject emerges as a lack produced by the distance that separates their own self-image from that of the pluralist constitutional polity. Constitution making, moreover, can be regarded as an attempt to make up for this lack, by reaching to the other to forge a common identity rooted in a shared constitutional text. But, because neither the language of the self nor that of the other is suited to express their common vision, the emerging constitutional discourse must inevitably enter the scene sounding like a foreign language, thus alienating all those who must learn how to use it.

More specifically, modern constitutionalism requires limited government, adherence to the rule of law, and protection of fundamental rights. ${ }^{42}$ Consistent with this, victorious revolutionaries who undertake the role of constitution makers must stake their claim to occupying the place of legitimate constitutional subject by renouncing a significant amount of power, submitting to the prescriptions of law, and refraining from impinging on the fundamental interests of others. There are, of course, many different ways in which constitution makers may seek to fulfill the conditions for

40 Cf. Georg W.F. Hegel, Hegel's Science of Logic 115, 122-29 (H.D. Lewis ed. \& Arnold V. Miller trans., Humanities Press Int'l 1989) (1812-1818) (all negation is determination).

41 See Gustave Le Bon, The Psychology of Revolution 18, 168-70 (Bernard Miall trans., G.P. Putnam 1913) (1912).

42 Michel Rosenfeld, Modern Constitutionalism as Interplay Between Identity and Diversity: An Introduction, 14 CARDozo L. REv. 497, 499 (1993). 
emergence of a legitimate constitutional subject, but they all involve alienation of power and a construction of self-identity dependent on the will and self-image of the other. To take but one example concerning modern constitutionalism's requirement of limited government, it is instructive to compare the distinct approaches employed in the eighteenth century by American and French constitution makers, respectively. In the United States, limited government was sought to be achieved through a division of powers between the federal and state governments, ${ }^{43}$ and between the three branches of the federal government. ${ }^{44}$ Underlying this stress on the division of powers is the conviction that, even in a democracy, unchecked political power tends toward abuse, ${ }^{45}$ which can be prevented through the institution of a system based on "checks and balances." Thus, from the standpoint of the American constitution makers, opting for limitations on powers pursuant to a scheme of "checks and balances" meant a renunciation and alienation of much of the power generated as a consequence of the triumph of the American Revolution. From the perspective of the definition of the self-identity of the American polity framed by the Constitution, on the other hand, the division of powers makes the identity of the whole dependent on clashes between the identities of the various parts. For example, federalism must mediate between a national identity shaped by federal interests and various state identities. ${ }^{46}$ Accordingly, neither the national identity nor that of the states can prevail as the self-identity that encompasses the polity as a whole. Instead, both national identity and state identities must struggle and, in important respects, yield to one another in the course of striving towards a coherent self-identity of the constitutionally structured polity as a whole.

In contrast to the American Constitution, the French Constitution of 1793 vests supremacy on the national legislative branch, ${ }^{47}$ thus promoting the idea that democratic values are best instituted through undivided state powers. This idea, moreover, is grounded on the notion that limited government is best achieved through de-

\footnotetext{
43 See, e.g., Gerald Gunther, Construttional Law 77 (12th ed. 1991).

44 See U.S. Const. arts. I, II, III (enumerating respectively the legislative, executive, and judiciary power of the United States government).

45 See, e.g., The Federal.ist No. 57 (James Madison).

46 This effort at mediation does not always lead to smooth or stable results. Compare, e.g., National League of Cities v. Usery, 426 U.S. 833 (1976) (federalism prohibits imposing certain federal labor standards on employees of a state) with Garcia v. San Antonio Metro. Transit Auth., 469 U.S. 528 (1985) (federalism permits imposing the same labor standards on employees of a state).

47 See Const. (1793) art. I (Fr.).
} 
mocracy based on universal and rational values informed by a Rousseauian conception of the general will. ${ }^{48}$ Notwithstanding that the self-identity of the French constitutional government originates in unity rather than in division, however, it ultimately requires no less alienation and deference to the other than does its American counterpart. Indeed, below the surface, the unity fostered by the general will dissolves into a series of oppositions in which the conflict between self and other is displaced but not overcome. In Rousseau's conception, the general will is neither the will of the individual, nor even that of the majority. Instead, as Rousseau sees it, the general will is the sum of the differences between all the individual wills, or the "agreement of all interests" which "is produced by opposition to that of each." 49 In sum, whereas in the United States the construction of constitutional self-identity through limited government must account for divisions among various factions, in France the unity of self-identity may be served through the general will, but only at the price of allowing the other into the inner precincts of the self. Thus, under the strain of the general will, the individual must split into two oppositional figures: that of the publicly spirited citizen, and that of the privately motivated bourgeois. ${ }^{50}$

Based on the lack and alienation that emerge out of the self's encounter with the other, the constitutional subject finds itself in a position that requires it to forge its identity through the medium of a constitutional discourse, embedded in a common language, that binds together the multifaceted constitutional self with its multiple others. This constitutional discourse, moreover, must build upon a constitutional text ${ }^{51}$ which must be placed in its proper context, taking into account relevant normative and factual constraints. As text is dependent on context, and as the context is open-ended and subject to transformation over time, the constitutional subject must resort to constitutional discourse to invent and reinvent its identity. In other words, motivated by the urge to overcome its lack and its inherent incompleteness, the constitutional subject must avail itself

48 See Rousseau, supra note 17 , at $15-18$.

$49 \mathrm{Id}$. at $26,26 \mathrm{n} .2$.

so See Rosenfeld, supra note 17 , at $869-70$ (Rousseau locates conflict between private and common interest within the individual and links bourgeois and citizen through internalization of the public interest.).

51 The constitutional text in question may, but does not have to, be a written constitution. Indeed, an unwritten constitution can function just as a written one inasmuch as they can both be regarded as texts which depend for meaning on context. 
of the tools of constitutional discourse to construct a coherent narrative in which it can locate a plausible self-identity.

\section{B. Construction and Reconstruction of Constitutional Identity}

Once it is admitted that the constitutional subject can only acquire an identity in the intersubjective realm circumscribed by constitutional discourse, it should become apparent that personifying the constitutional subject ought to be avoided. Neither the constitution makers, nor the interpreters of the constitution, nor those who are subject to its prescriptions, are properly speaking the constitutional subject. They all form part of the constitutional subject and belong to it, but the constitutional subject as such can only be grasped through expressions of its self-identity in an intersubjective discourse linking all the human actors who were, are, and will be brought together by the same set of constitutional norms. The full expression of constitutional self-identity is only conceivable through an imaginary exercise involving an extreme compression of all times, and a simultaneous grasp of all possible interpretive variations, combined with an ability to distill it all into an authoritative and coherent narrative. Short of that, however, constitutional self-identity can only be articulated piecemeal by a partial subject who must construct it from disparate fragments that need to be projected into an uncertain past and future. Moreover, for such construction to escape being perceived as merely arbitrary, it must be supplemented by a reconstruction. As we will see, the construction affords but a glimpse of constitutional identity, and the function of the reconstruction is to transform that glimpse into a determinate image.

To understand the relationship between construction and reconstruction, one must bear in mind that constitutional self-identity revolves around the antinomies between fact and norm, and between real and ideal. The antinomy between fact and norm manifests itself through the juxtaposition of constitutional norms, and sociopolitical and historical facts, as well as, through the conflict between an actual existing constitution and the normative requirements of constitutionalism. In terms of the relationship between constitutional norm and historical fact, application of the same constitutional norm may lead to different outcomes, depending on the relevant historical facts. Thus, for example, because of different experiences with Nazism at home, similar freedom of expression norms are respectively interpreted as protecting pro-Nazi 
speech in the United States, but not in Germany. ${ }^{52}$ Also, different factual conditions may in certain circumstances change the meaning of the same constitutional norm. For example, a constitutional right to subsistence may well amount to a legal guaranty in an industrially advanced society, but can be no more than an aspirational hope in an underdeveloped country with widespread starvation.

The conflict between actual constitutions and constitutionalism as embodying certain normative prescriptions, is in a sense a clash between the fact of a particular constitution and the norms that prescribe what constitutional democracy ought to be. This conflict, however, can also be viewed as a clash between different norms, namely between those norms promoted by an actual constitution and inconsistent norms inherent in constitutionalism. Dealing with such inconsistencies, as we shall see, is one of the important tasks that might be best handled by reconstruction.

The antinomy between the real and the ideal figures prominently in the determination of the self-identity of the constitutional subject as a consequence of the limitations and deficiencies inherent in the actual empirical and historically determinate position of that subject. The reality of the constitutional subject, as riddled by lack and incompleteness, is too impoverished to generate a viable self-identity capable of furnishing a coherent grounding for the constitutional order. Thus, for example, from the limited and fragmented perspective of the single constitutional judge, who at best has a partial and incomplete access to the empirical reality of the constitution makers and but the faintest insight into the reality of future generations, it seems all but impossible to develop a coherent picture of constitutional self-identity based exclusively on historically accessible and empirically verifiable data. Because of this inherent poverty of the real, it is necessary to have recourse to the ideal to frame an adequate conception of constitutional self-identity. Indeed, inasmuch as we cannot see from our own limited historical vantage point, the constitutional self of which we are a part, we must strive to imagine it. To establish a viable constitutional self-identity, the real must be supplemented by the ideal, or, to put it in another way, facts must be enriched by counterfactual imagination. Consistent with this, construction and reconstruction are meant to erect bridges linking the real to the ideal, and facts to counterfactuals. However, because the ideal not only supplements the real but also contradicts it, construction and reconstruction,

52 See Schauer, supra note 16 , at $877-79$. 
while necessary, are dangerous tools which must be properly used and adequately legitimated.

Construction and reconstruction to deal with antinomies between fact and norm, and between the real and the ideal, have a long and venerable lineage that includes the reconstructive theories of, among others, Hobbes, Rousseau, Kant, Rawls, and Habermas. ${ }^{53}$ Moreover, reconstructive theory has been creatively applied in legal and constitutional interpretation by Ronald Dworkin. ${ }^{54}$ Since an infinite variety of ideals are imaginable, however, the key to properly assessing the worth of a particular reconstructive theory lies in determining the logic and persuasiveness with which that theory matches the real and the ideal, or facts and the counterfactual imagination..$^{55}$ Furthermore, two different purposes are likely to inform reconstructive attempts at matching the real and the ideal. To the extent that the ideal is conceived as supplementing the real, reconstructive theory is oriented towards grounding a normative justification for the status quo. ${ }^{56}$ On the other hand, insofar as the ideal is regarded as contradicting the real, reconstructive theory is primed to furnish a critique of existing institutions. . $^{57}$

Construction and reconstruction represent two distinct moments in the ongoing quest to obtain a better grasp of the evolving and incomplete self-identity of the constitutional subject. Constitutional decision making always arises under conditions that preclude full determinacy, and makes construction necessary. In fact, constitutional decision making involves construction to the extent that constitutional issues always require making choices between two or more plausible alternatives. Thus, for example, the 1973 decision by the United States Supreme Court in Roe v. Wade, ${ }^{58}$ recognizing for the first time a constitutional right to abortion, certainly involved creative judicial construction. Indeed, neither the text of

53 See Michel Rosenfeld, Law as Discourse: Bridging the Gap Between Democracy and Rights, 108 Harv. L. Rev. (forthcoming March 1995) (reviewing Jurgen Habermas, Between Facts and Norms: Contributions to a Discourse Theory of Law and DeMOCRACY (forthcoming 1995)).

54 See Ronald Dworkin, LAw's EMPIRE (1986).

55 For an excellent discussion of counterfactual imagination in the context of Habermas's work, see Michael Power, Habermas and the Counterfactual Imagination, 17 CARdozo L. Rev. (forthcoming 1995) (manuscript on file with author).

56 Rawls's use of "reflective equilibrium" provides a good example of how reconstructive theory pursues his objective. See JOHN RAwL, A THEORY OF Justice 20-21, 48-51 (1971); see also Power, supra note 55.

57 See Rosenfeld, supra note 53 (perfect market ideal can be used to criticize view that actual markets are self-legitimating).

58410 U.S. 113 (1973). 
the Constitution nor previously articulated Supreme Court jurisprudence could fairly be taken to compel or preclude the decision reached by the Court. Moreover, the act of judicial construction that resulted in the holding in Roe had an unmistakable and significant impact on the constitutional identity of the United States. On the one hand, given the nature of the religious, moral, and political debate concerning abortion, recognition of a constitutional right to abortion projects a noticeably different image of American constitutional identity than that which would have emerged had the Supreme Court refused to recognize such a right. On the other hand, given the bitter controversy that followed the Roe decision ${ }^{59}$ and the vigorous efforts over the years to have the Roe decision overturned, ${ }^{60}$ it is hardly an exaggeration to claim that it provoked a crisis in the constitutional identity of Americans.

Although $R o e$ is exceptional because of the magnitude of its impact on the American constitutional identity, all significant constitutional decisions have some impact on constitutional identity and hence call for justification. Reconstruction affords the means to tackle the task of justification and makes possible cogent vindication or condemnation of the constructs associated with constitutional decision making. In other words, constitutional interpretation and elaboration introduce new elements that have a bearing on the makeup of constitutional identities. The task of reconstruction is to harmonize these new elements with previous existing ones; or, to the extent that the new elements disrupt relationships established among previously existing elements, to recombine all the elements involved into an intelligible and cogent picture. Such harmonization or recombination, however, cannot be achieved exclusively on the basis of the fragmentary reality which it confronts, and thus calls for the exercise of our counterfactual imagination.

As already mentioned, not all products of our counterfactual imagination are apt to result in an acceptable or useful reconstruction. For instance, a counterfactual solely contrived to vindicate

59 See Laurence H. Tribe, Abortion: The Clash of Absolutes 6-7, 139 (2d ed. 1992); Lawrence Van Gelder, Cardinals Shocked-Reaction Mixed, N.Y. TIMEs, Jan. 23, 1973, at A1; Tamar Lewin, Legal Abortion Under Fierce Attack 15 Years After Roe $v$. Wade Ruling, N.Y. Times, May 10, 1988, at A20; Statements By 2 Cardinals, N.Y. Times, Jan. 23, 1973 , at A20.

60 See, e.g., TRIBE, supra note 59, at 161-70; Linda Greenhouse, Reagan Administration Renews Assault on 1973 Abortion Ruling, N.Y. Times, Nov. 11, 1988, at A20; Leslie H. Gelb, U.S. Will Ask Court to Reverse Abortions Ruling, N.Y. TimEs, July 15, 1985, at A1; Transcript of Oral Arguments Before Court on Abortion Case, N.Y. Times, Apr. 27, 1989, at B12. 
the status quo at all costs, or an ideal set so high as to make all conceivable constitutional arrangements grounded in reality appear to be illegitimate, would seem a misuse of reconstruction. By contrast, a reconstructive approach, such as that of Dworkin, which relies on certain attractive normative presuppositions and makes use of a consistent standard to keep the counterfactual imagination within acceptable bounds, certainly seems much more apt to measure up to the task. Dworkin insists that reconstructive judicial interpretation revolves under two fundamental requirements: first, acceptance of certain deontological principles, such as the right of each person to equal respect and dignity; and second, adherence to a uniform and coherent standard, namely that of integrity, which demands consistency between every new judicial interpretation and the corpus of past judicial interpretations. ${ }^{61}$ The first of these requirements is highly commendable in that it furnishes a widely accepted normative criterion that equally embraces the self and the other, whose common bond is so essential to constitutional selfidentity. The second of Dworkin's requirements, however, is ultimately inadequate inasmuch as his notion of integrity is too amorphous to furnish sufficient structure to the counterfactual imagination. ${ }^{62}$

Building upon Dworkin's first requirement, it seems advisable to submit reconstruction, as it relates to the discovery of the identity of the constitutional subject, to the normative constraints inherent in constitutionalism. Indeed, all these constraints-namely, commitment to limited government, adherence to the rule of law, and protection of fundamental rights - promote mutual recognition between self and other, and maintain self and other on a footing of equal dignity. ${ }^{63}$ Moreover, by submitting to these constraints, reconstruction naturally lends itself to the task of evaluating the legitimacy of actual constitutional norms.

In addition to requiring compliance with the constraints of constitutionalism, counterfactual reconstruction could be strength-

61 Dworkin has analogized the interpretative task of the judge under his reconstructive theory to the task confronting the author of a chain novel who must build the best possible narrative consistent with the contribution of his or her predecessors. See DworkIN, supra note 54 , at $228-32$.

62 For a more extensive critique of Dworkin along similar lines, see Alan Brudner, The Ideality of Difference: Toward Objectivity in Legal Interpretation, 11 CARDOzO L. Rev. $1133,1156-58$ (1990).

63 Specifically, the limitation on the power of the governors implies recognition and deference to the dignity of the governed. Adherence to the rule of law, understood as equality before the law and under the law, likewise promotes respect between self and other. Ditto for the protection of fundamental rights. 
ened by supplementing Dworkinian integrity with a condition of logical plausibility, to be assessed in terms of prevailing circumstances. This latter condition, inspired by Hegel's conception of the subject as evolving through a series of different stages, ${ }^{64}$ mandates a contextually grounded reconstruction adapted to the actual tensions and contradictions found within prevailing social and political relations. At each stage of its historical development, the constitutional subject encounters certain contradictions that motivate it to seek coherence through use of counterfactual imagination. Accordingly, reconstruction seems most useful if it points to a plausible resolution of prevailing contradictions by elaborating a counterfactual picture that does not exceed the horizon of possibilities delimited by existing material conditions. In sum, from the standpoint of the identity of the constitutional subject, the legitimacy of reconstruction depends on adherence to the norms embodied in constitutionalism, coupled with respect for the limits imposed by the relevant horizon of possibilities.

\section{The Reconstructive Tools of Constitutional \\ Discourse: Negation, Metaphor, and Metonomy}

Constitutional discourse must articulate a self-identity by means of a counterfactual narrative that takes into account both the applicable constitutional text and the normative constraints flowing from constitutionalism. Such a narrative, moreover, must strive to bridge the gap that splits the constitutional subject into self and other, while, at the same time, furnishing sustenance to the constitutional subject by endowing it with a distinct identity. From the standpoint of those who seek to vindicate the constitutional status quo, constitutional discourse must bridge the gap between the actual constitution and the precepts of constitutionalism, and forge sufficient common grounds between self and other to lend the requisite support for the constitutional subject to maintain a distinct identity. From the standpoint of those who appeal to the counterfactual imagination to launch a critique of existing constitutional arrangements, on the other hand, constitutional discourse must expose mere semblances of harmony between the constitution and constitutionalism, and pierce through constitutional identities that oppress or unduly constrain self or other. Whether constitutional discourse is used to justify or to criticize existing con-

64 For a summary of the essential aspects of Hegel's dialectic of the subject, see Michel Rosenfeld, Hegel and the Dialectics of Contract, 10 Cardozo L. Rev. 1199, 1207-09 (1989). 
stitutional arrangements, however, it operates mainly by means of the same essential tools: negation, metaphor, and metonymy.

Negation, metaphor, and metonymy combine to select, discard, and organize pertinent elements with a view to producing a constitutional discourse in, and through which, the constitutional subject can ground its identity. Negation is crucial to the extent that the constitutional subject can only emerge as distinct, through exclusion and renunciation. Metaphor or condensation, on the other hand, which proceeds by stressing similarities at the expense of differences, plays a key unifying role, in producing partial identities around which constitutional identity can revolve. ${ }^{65}$ Finally, metonymy or displacement, with its emphasis on contiguity and context, is essential to guard against the constitutional subject fixating on identities that remain so condensed and abstract as to gloss over the differences which must be taken into consideration if constitutional identity is genuinely to encompass both self and other. An accurate picture of how constitutional discourse can shape the identity of the constitutional subject through the work of negation, metaphor, and metonymy, depends on a proper account of the interaction between the three. Indeed, it is through such interaction that constitutional discourse acquires determinate meaning. But before examining how negation, metaphor, and metonymy interact, it is necessary to look at each of them individually to get a better handle on their respective roles in shaping constitutional discourse.

\section{A. Negation}

The role of negation in the process of establishing the identity of the constitutional subject is multifaceted, intricate, and complex. It involves, among other things, rejection, repudiation, repression, exclusion, and renunciation. These functions, moreover, may intertwine in various ways and simultaneously operate at different levels of reality. In view of this rich diversity, I can only briefly outline some of the most general aspects of the essential contribution of negation to the definition of constitutional self-identity.

In the broadest terms of Hegel's conception of the dialectic of the subject, negation provides the fundamental link between the initial stage in which the subject emerges as mere lack and the final stage in which the subject becomes substance, or in other words, in

65 See Rosenfeld, supra note 42, at 498 (national, regional, linguistic, religious, ethnic, political, and ideological identities are likely to figure in the determination of constitutional identity). 
which the subject becomes for-itself as it is in-itself. ${ }^{66}$ Pursuant to Hegel's dialectic logic, the subject first acquires its own identity by negating that it is reducible to the objects of its desire. That initial identity of the subject, however, is purely negative and oppositional as it focuses upon what the subject is not, without revealing what it is. After having emerged as pure negation, the Hegelian subject enters into the next stage of its logical evolution ${ }^{67}$ in search of a positive identity. In the course of this search, the subject negates that it is merely the lack that emerged in the first stage, and seeks a positive identification in the manifold diversity of its concrete manifestations. But as it embraces these manifestations, the subject loses sight of its unity, and is thus unable to grasp its emerging positive identity as its own. Moreover, because of this inability, the subject becomes alienated from itself. In the third stage, the Hegelian subject, through a negation of the (second stage) negation, finally assumes its positive identity as its own, thus becoming for-itself what it is in-itself.

The path towards the establishment of the identity of the constitutional subject can be reconstructed as a three stage process conforming to Hegel's dialectical logic of the subject. In the first stage, the constitutional subject's identity can be conceived as pure negation because the constitutional subject acquires a distinct identity by negating that it is (the same as) the preconstitutional subject, or a mere product of existing cultural, historical, ethnic, or religious identities. In other words, the constitutional subject first enters the scene, by cutting loose from all those already constituted subjects found within the relevant spaciotemporal framework. Moreover, the constitutional subject arrives at this purely negative identity through: repudiation of the (prerevolutionary) past; rejection of traditional identities; repression of the urge to embrace a dominant, positive identity to the detriment of the plurality of (nonconstitutional) identities sought to be protected by constitutionalism; exclusion of any militantly antipluralistic tendency that would defeat constitutionalism; and, renunciation of dreams of hegemony by those in a position to shape the destiny of the constitutional subject.

As pure negativity, the constitutional subject experiences itself as a lack, and consequently strives to fill the void within itself, by

66 See Rosenfeld, supra note 64, at 1208 \& n.51, 1209.

67 In the context of Hegel's dialectic of the subject, logics cannot be separated from ontology, so that, strictly speaking, Hegel provides us with what Jean Hyppolite has called an "onto-logic" of the subject. See HYPPOLITE, supra note 32, at 554. 
developing a positive identity. The search for a positive identity marks, moreover, the second stage in the logical development of the constitutional subject. But such positive identity only proves possible if recourse is had to the very identities discarded in the first stage of the constitutional subject's formation. Indeed, the objectives of constitutionalism cannot be pursued in a vacuum; they require establishing a viable institutional apparatus that must, of necessity, draw upon the history, traditions, and cultural patrimony of the relevant polity.

Recourse to identities discarded during the first stage does not signify, however, a return to the realm of the preconstitutional. Consistent with Hegelian logic, the dialectical transition from one stage to the next involves a process of "Aufhebung" or sublation, whereby what emerges in the first stage is at once preserved and transcended within the perspective of the second stage. ${ }^{68}$ Applied to the constitutional subject, this means that the second stage is marked by a selective incorporation of discarded identities rather than by any wholesale return to preconstitutional identities. In other words, the traditions incorporated into the constitutional subject during the second stage are not pursued for their own sake. Instead, these traditions are only invoked inasmuch as they are capable of serving the interests of constitutionalism.

The logic that underlies the development of the constitutional subject is analogous to that which informs the implantation of pluralism as a comprehensive conception of the good. ${ }^{69}$ Accordingly, a brief glance into the first two logical moments of pluralism will serve to provide a more vivid illustration of the constitutional subject's transition between stage one and stage two. In the broadest terms, pluralism seeks to promote the greatest possible diversity of conceptions of the good as a means to maximize human dignity and autonomy. ${ }^{70}$ Consistent with this, pluralism's first moment must be a negative one, whereby it denies all competing conceptions of the good (except that of pluralism), exclusivity, or predominance. Thus, for example, pluralism must combat intolerant religions

68 As Hegel states: "To transcend (Aufheben) has this double meaning, that it signifies to keep or to preserve and also to make to cease, to finish.... Thus, what is transcended is also preserved; it has only lost its immediacy and is not on that account annihilated." 2 GeORG W.F. Hegel, SCIENCE of LoGic 119-20 (W.H. Johnston \& L.G. Struthers trans., George Allen \& Unwin Ltd. 1966) (1812-1816).

69 This is hardly surprising given that constitutionalism depends on pluralism and can ultimately be regarded as providing the means to institutionalize pluralism.

70 For a more extensive discussion of pluralism as a substantive conception of the good, see Michel Rosenfeld, Autopoiesis and Justice, 13 CArdozo L. Rev. 1681, 1694-95, 170911 (1992). 
claiming a monopoly on the truth. Carried to its logical extreme, however, pluralism's first moment leads to self-destruction. Indeed, if all conceptions of the good are thoroughly countered, the very diversity sought by pluralism would become meaningless. To avoid self-destruction, pluralism must therefore supplement its negative moment with a positive one, whereby excluded conceptions of the good are readmitted into the pluralist universe. But the readmitted conceptions cannot occupy the same position that they had prior to their expulsion. For example, religions are only readmitted on the condition that they pose no threat to other religions or to nonreligious conceptions of the good. And this can be accomplished by relegating readmitted religions to the private sphere. $^{71}$

Analogously, as partial preconstitutional identities become incorporated into the constitutional subject during its second stage of logical development, they combine in novel ways and come to occupy different positions from those they occupied in the preconstitutional era. Imagine, for example, that a polity divided into several different regions along ethnic and religious lines decides to become a constitutional democracy, and opts for a federal system of government. Under such a federal system, moreover, imagine that each ethnically and religiously homogeneous region were to be accorded equal representation in the upper chamber of the national legislature, but that representation in the lower chamber were exclusively a function of the size of the population, with the consequence that more numerous ethnic groups would be likely to achieve greater representation than their less numerous counterparts. Finally, assume that the constitution in this new federal democracy divides the sovereign powers of the state between the national legislature and the respective legislatures of the various constituent states, based on a desire to institute a system of "checks and balances." Under these circumstances, the identity forged by the new federal democracy would be neither that projected by the national legislature, nor that put forth by the various state legislatures. Instead, the identity of the new federal democracy would seem bound to be grounded in the opposition between state and national legislatures. Furthermore, existing ethnic and religious identities would certainly figure in the identity of the new federal

71 Cf. Karl Marx, On the Jewish Question (1843-1844), in WRITINGs OF THE YOUNG Marx on Philosophy and Society 216-48 (Loyd D. Eason \& Kurt H. Guddat eds. \& trans., Anchor Books 1967) (arguing that religious emancipation can only be obtained at the cost of relegating religion to the private sphere). 
democracy, but they would do so in a significantly transformed way. Thus, points of convergence would more likely be stressed than points of divergence; some differences would probably be left out altogether through the implementation of "gag rules"; $; 2$ and some particular ethnic and religious identities would inevitably figure more prominently than others, either because of their spread over greater numbers, or for other reasons.

In the process of incorporating the partial identities that enable it to project a positive image, the constitutional subject is bound to become alienated. Because of its initial lack of positive identity, the constitutional subject is forced to turn outward to other identities. But as the process of incorporating the latter unfolds, the constitutional subject becomes prey to outside influences that appear to be beyond its control. Thus, the very necessity of acquiring a positive identity leads the constitutional subject to a confrontation between survival and loss of subjectivity. Pursuant to the dictates of dialectical logics, therefore, the constitutional subject must negate its subjectivity to maintain an identity.

The culmination of the dialectical evolution of the constitutional subject is brought about by yet another reversal of perspective made possible by the work of negation. In this case, it is the negation of the negation-or, in other words, the negation of the proposition that the pursuit of identity entails the loss of subjectivity-which allows the constitutional subject to reach a vantage point from which it can perceive its unfolding positive identity as being ultimately shaped by its own will, rather than by outside forces beyond its control. Specifically, the negation of the negation has completed its work when the constitutional subject realizes that, although the raw materials that figure in its positive identity originate in the outside objective world, their selection, combination, organization, and deployment into a coherent whole is the product of its own work, of its own efforts to strive towards a distinct identity. Here again, the analogy to pluralism is instructive. As will be remembered, pluralism must reincorporate in its positive moment conceptions of the good that it excluded in its negative moment. But which such conceptions of the good are to be thus reincorporated, and to what extent, is determined by the normative criteria imposed by pluralism, thus making it clear that pluralism's tolerance of diverse conceptions of the good results from an active rather than passive stance. Likewise, the constitutional

72 See Stephen Holmes, Gag Rules or the Politics of Omission, in Constitutionalism AND DemOCRACY 19-58 (Jon Elster \& Rune Slagstad eds., 1988). 
subject's construction of its positive identity cannot be completed without subjecting the raw material originating outside the constitutional sphere to the normative constraints prescribed by constitutionalism.

Negation is not only a crucial tool in the constitutional subject's pursuit of the ideal defined by constitutionalism, but also in its endeavors to negotiate the space that separates actual constitution from the normative universe of constitutionalism. To the extent that an actual constitution-either because of its textual provisions or its interpretive or implemental practices-falls short of the fundamental prescriptions of constitutionalism, negation is bound to figure as an essential tool both at the level of construction and at that of reconstruction. A particularly good example of this is provided by the contradictions that surround the United States Constitution of 1787. As already mentioned, the "We The People" of the 1787 Constitution's Preamble, who are, at least nominally, the relevant constitutional subject at the birth of the American Constitution, must be linked to the "all men are created equal" of the 1776 Declaration of Independence. But by condoning slavery ${ }^{73}$ the 1787 Constitution became mired in a glaring contradiction in relation both to its own historical and ideological premises, and to the fundamental prescriptions of constitutionalism. The use of negation thus became important to cope with these contradictions. On the one hand, by not importing "all men are created equal" into the constitutional text, those standing behind "We The People," could conceal the contradiction without eliminating either of its terms. Equality was recognized as an essential pillar of the entire constitutional project, but precisely because of its absence from the four corners of the constitutional text, it could be consistently rejected as an operative constitutional norm.

On the other hand, when it came to reconstruction to bridge the gap between the 1787 Constitution and constitutionalism, simply denying constitutional and legal force to the premises embodied in the Declaration of Independence, would not do. Indeed, purely textual solutions are inherently insufficient to deal with contradictions between constitution and constitutionalism. What is needed, instead, is some reconciliation at the level of concepts. Slavery is antithetical to the concept of equality embedded in constitutionalism. ${ }^{74}$ This notwithstanding, reconciliation was still possible through the use of negation. And, the tragic and shameful

73 See supra note 23 and accompanying text.

74 See Rosenfeld, supra note 42, at 502-03. 
solution-but nonetheless a solution-consisted in treating African Americans as being less than fully human. In other words, by negating that African Americans deserved to be treated as fullfledged human beings, slavery in America could somehow be reconciled with the precepts of constitutionalism. To be sure, this reconciliation would prove extremely precarious and it would produce monstrous results. This is perhaps best illustrated in the Supreme Court's infamous decision in Dred Scott, ${ }^{75}$ which provides one of the most glaring examples of how, through reconstruction based on negation, slavery and constitutionalism could be presented as compatible. Dred Scott dealt with the constitutionality of a federal law that provided for the emancipation of slaves upon being brought into federal territory by their owners. Dred Scott was thus emancipated, but upon his subsequent return to the state where he had been a slave, his former owner reclaimed ownership over him. The question before the Supreme Court was whether the federal statute providing for emancipation was unconstitutional as a violation of the slave owner's constitutionally protected property rights. ${ }^{76}$

The Court held that the federal statute providing for emancipation was indeed unconstitutional as violative of the legitimate property rights of the (former) slave owner, a decision that would have been patently incoherent but for the negation of full membership into the human race for African Americans. ${ }^{77} \mathrm{Had}$ the Supreme Court treated Dred Scott as a full human being, considering him property would have been preposterous. And even if the Court had acknowledged that the Constitution condoned slavery in the states that made it legal, it could still have held, without doing violence to the constitutional text or to accepted canons of interpretation, that once on federal territory Dred Scott had acquired full citizenship, and accordingly, his liberty Due Process rights had to prevail over any property rights that his former owner might have possessed. But if the Supreme Court had decided for Dred Scott, it would have officially acknowledged a glaring contradiction

7560 U.S. (19 How.) 393 (1857).

76 The slave owner's asserted property right was based upon the Due Process Clause of the Fifth Amendment, which provides that "no person shall be ... deprived of life, liberty, or property, without due process of law ...." U.S. Const. amend V. Arguably, Due Process rights are purely procedural, but for the first time in Dred Scott, the Supreme Court interpreted the Due Process Clause as protective of substantive property rights.

77 In his opinion, Chief Justice Taney stated that at the time of the Declaration of Independence and the adoption of the 1787 Constitution, African Americans had "been regarded as beings of an inferior order, and altogether unfit to associate with the white race ... and so far inferior, that they had no rights which the white man was bound to respect." Dred Scott, 60 U.S. (19 How.) at 407. 
between the Constitution and constitutionalism. By deciding as it did, the Court upheld the facade that linked the Constitution and constitutionalism, but it did so at the high price of accelerating the country's plunge into bloody civil war. Finally, whereas negation made possible the albeit precarious and ephemeral reconciliation between the Constitution and constitutionalism during the time of slavery, it also made possible the condemnation of the 1787 Constitution as inconsistent with the fundamental precepts of constitutionalism. For all those who share the belief that "all men are created equal" admits of no exceptions, condoning slavery negates the possibility of satisfying the requirements of constitutionalism.

\section{B. Metaphor}

If negation is crucial inasmuch as identity can only be conceived in terms of what one is not, metaphor is essential to the interplay between identity and difference that sustains the constitutional subject's quest for a positive self-identity. As a tool designed to establish similarities and equivalences, metaphor provides the discursive underpinning for the pole of identity in the dialectic between identity-in the sense of sameness-and difference. Through a process of combination and substitution, metaphor ferrets out similarities and equivalences to forge links of identity.

Metaphor is the discursive equivalent of Freud's concept of condensation. According to Freud, condensation is a psychic process whereby similarities are drawn together and emphasized, at the expense of differences. In the context of dream formation, for example, the image of a single face can serve as a representation of several different persons, by means of the work of condensation, which consists of drawing a composite picture that emphasizes common facial features and disregards or cancels out divergent ones. $^{78}$ Moreover, by combining and organizing complex and multifaceted elements in terms of similarities, condensation makes possible, or sharpens, our grasp of where genuine identities might be found. Condensation, however, can also perform a function of substitution, whereby an objectionable picture can be replaced by a composite substitute made up of similar but not identical features. For example, imagine that a single face made up of a composite of similar facial features belonging to different persons symbolizes in a dream those persons to whom the dreamer is sexually attracted. Suppose further, that sexual attraction to one of the symbolically

78 See Sigmund Freud, The Interpretation of Dreams 327-28 (James Strachey ed. \& trans., Avon Books 1965) (8th ed. 1930). 
represented persons could not be consciously acknowledged, because it would violate a fundamental taboo. Under these circumstances, condensation serves to conceal the forbidden attraction by substituting the actual features of the person who is the object of such attraction with similar features, which are close enough to permit an unconscious link, yet removed enough to protect the dreamer from becoming conscious of his or her forbidden desire. In short, through substitution along a series of similar, though not identical, features, condensation opens a channel of expression for repressed material. As we shall see, moreover, the availability of an analogous channel of expression for the constitutional subject is important. It allows for both substitutions of identities incompatible with the constitutional order, and for criticism of identities associated with the constitutional subject as mere stand-ins for identities that ought to be banished.

Through his concept of metaphor, Lacan systematizes Freud's notion of condensation in the context of linguistic theory. ${ }^{79}$ Building on Roman Jakobson's linguistic theory, ${ }^{80}$ Lacan conceives of the metaphoric function as establishing relationships of similarity. ${ }^{81}$ Meaning, moreover, is generated through interaction between the metaphoric function and the metonymic function..$^{82}$ Metaphor contributes to the production of meaning by cementing relationships of similarity in reference to a code, or, in other words, by linking signs along a paradigmatic axis. ${ }^{83}$

The metaphorical function plays an essential role both in legal rhetoric and in constitutional discourse. Legal argumentation relies prominently on establishing analogies and similarities, as vividly exemplified by common law adjudication based on precedent. Let us assume, for example, that there is judicial precedent to the effect that the owner of a house is liable for injuries suffered there by a person hired to do work in the house. Consistent with this, an attorney representing a houseguest suing the owner for injuries suffered there would seek to analogize the two situations, by emphasizing the similarities and downplaying the differences.

79 See Anthony Wilden, Lacan and the Discourse of the Other, in JACQUES LACAN, THE Language of the Self: The Function of Language in Psychoanalysis 157, 246 (Anthony Wilden trans., Dell Publishing Co. 1968) (1956).

80 See id. at 244.

81 ld.

82 The metonymic function and metonymy are discussed below. See infra section III.C.

83 See Roman Jakobson, Child Language Aphasia and Phonological Universals 70 (Allan Keiler trans., 1968) (the relation of substitution or "between elements of one and the same series of alternations is called associative, or, following the more exact term of Hjelmslev, paradigmatic"). 
In the realm of constitutional discourse, on the other hand, metaphor not only operates at the level of rhetoric, but also contributes in setting the cardinal reference points of the constitutional order. Beginning with "all men," in the sense of all humans, "are created equal," underlying the postulate of equality on which modern constitutionalism rests, ${ }^{84}$ there are a large number of fundamental constitutional constructs that rely heavily on metaphorical processes. Thus, "all men are created equal" certainly emphasizes similarities at the expense of differences, and, on close inspection, may ultimately depend more on substitution than on combination. Indeed, it is not so much the fact that all human beings share certain characteristics in common, but rather the counterfactual proposition that all human beings are equal as moral agents, that forms the backbone of the normative universe associated with constitutionalism. ${ }^{85}$

Metaphor also figures in the famous American dictum that "the Constitution is colorblind." ${ }^{36}$ Concentrating on the metaphoric qualities of this dictum ${ }^{87}$ reveals that it results from emphasis on the similarities between the races-that is, those things which they share in common in spite of their racial differencescoupled with disregard for racial differences, and for that which must be deemed to arise as a consequence of these differences. In other words, through combination and substitution, the metaphor of colorblindness brackets off racial differences and differences associated with race. This metaphor, moreover, legitimates constitutional doctrine that prohibits legal classifications based on race, and promotes a constitutional identity that rises above the divisiveness of racial politics. From a normative standpoint, constitutional doctrine backed by the metaphor of colorblindness has the virtue of prohibiting the use of racial differences as a means to legally disadvantage oppressed racial minorities. By the same token, however, such legal doctrine can also inhibit the march towards racial justice. For example, if strictly applied, legal doctrine based on the

84 For a more extended discussion of the postulate of equality and its relation to American Constitutionalism, see Rosenfeld, supra note 15 , at $21,135-36$.

85 See id. at 20-21.

86 Plessy v. Ferguson, 163 U.S. 537, 559 (1896) (Harlan, J., dissenting).

87 This dictum also evinces a strong imprint of negation. In a society so constantly attuned to racial differences, colorblindness stands in direct contradiction to prevailing social mores. Therefore, for colorblindness to become incorporated into constitutional identity would require the negation of a defining aspect of the country's national identity. 
principle of colorblindness would prohibit any race-conscious remedy as a means to integrate racially segregated public schools. ${ }^{88}$

The range of the metaphoric function within the realm of constitutional discourse extends beyond equality rights. Indeed, other rights, such as privacy rights as conceived by the United States Supreme Court, and freedom of speech rights, also depend to a significant extent on the deployment of relationships of similarity. A particularly telling example is the United States Supreme Court's handling of the claim that constitutional privacy ought to be extended to protect sexual relationships among consenting homosexual adults in Bowers v. Hardwick. ${ }^{89}$ Against the background of its precedents extending constitutional privacy protection to consensual heterosexual sex among adults, ${ }^{90}$ the Supreme Court, in a five-four decision, held that consensual homosexual sex among adults was not a protected constitutional privacy right. The Court's majority emphasized that homosexual sodomy had traditionally been forbidden and criminalized, ${ }^{91}$ and a concurring opinion noted its condemnation under Judeo-Christian morals and ethical standards. ${ }^{92}$ The dissenting Justices, however, did not dwell on the treatment of homosexual sex in different cultures throughout history. Instead, they focused on similarities between heterosexuals and homosexuals, and through metaphorical thinking managed to depict them as being essentially similar. In the words of Justice Stevens,

From the standpoint of the individual, the homosexual and the heterosexual have the same interest in deciding how he will live his own life, and, more narrowly, how he will conduct himself in his personal and voluntary associations with his companions. State intrusion into the private conduct of either is equally burdensome. ${ }^{93}$

88 Cf. Swann v. Charlotte-Mecklenberg Bd. of Educ., 402 U.S. 1 (1971) (busing to integrate de jure segregated public schools permissible under the Equal Protection Clause of the Fourteenth Amendment). Although the idea of a colorblind constitution is often mentioned in the United States, it has thus far not been adopted by the Supreme Court. See, e.g., City of Richmond v. J.A. Croson Co., 488 U.S. 469 (1989) (all justices deem colorconscious remedies constitutionally permissible under certain circumstances).

89478 U.S. 186 (1986).

90 See Griswold v. Connecticut, 381 U.S. 479 (1965) (constitutional privacy rights bar state from prohibiting use of contraceptives by married couples); see also Eisenstadt v. Baird, 405 U.S. 438 (1972) (Griswold rights extend to nonmarried individuals).

91 Bowers, 478 U.S. at 192-94.

92 Id. at 196-97 (Burger, C.J., concurring).

$93 \mathrm{Id}$. at 218-19 (Stevens, J., dissenting). 
Thus, by moving away from the sexual practices involved, and from the historical, cultural, and religious mores concerning these practices, metaphorical reasoning leads to the abstract level where each individual is similar to every other individual, as possessing a need for intimate associations and as deserving privacy to freely pursue fulfillment of such a fundamental need. More generally, reaching higher levels of abstraction through metaphorical reasoning plays an important role in framing constitutional rights and in defining constitutional identity. As we shall see below, however, metaphorical ascent to the high levels of abstraction required to secure constitutional rights comes only at a heavy price. ${ }^{94}$

\section{Metonymy}

In contrast to metaphor's pursuit of similarities in relation to a code, metonymy promotes relations of contiguity within a context. ${ }^{95}$ As consideration of the dissent in Bowers v. Hardwick indicates, the metaphoric process tends to be acontextual, whereas the metonymic process represents the opposite tendency. Drawing again on Jakobson's linguistic theory, Lacan conceives of metonymy as the discursive embodiment of Freud's notion of displacement. ${ }^{96}$ According to Freud, displacement makes expression of repressed thoughts possible by redirecting them in all of their emotive intensity toward a target that bears a relationship of contiguity to the would-be target rendered inaccessible by repression. ${ }^{97}$ Thus, for example, if one's unconscious hatred of an uncle who uses a cane cannot find conscious expression because of repression, such hatred may be displaced toward canes, resulting in a conscious aversion to canes.

Elaborating on Freud's notion of displacement, Lacan envisages metonymy as symbolizing the flight of desire from object to object, as frustration stemming from the need to repress the original object of desire leads to the unsatisfactory pursuit of contiguous objects which might approximate, without ever matching, the original object. Thus, for Lacan, the metonymy of desire points to a lack of being, or in Hegelian language, to being-for-itself as a lack. ${ }^{98}$

94 See infra notes 145-46 and accompanying text.

95 See Wilden, supra note 79 , at $245-46$.

96 Id. at 244.

97 See Freud, supra note 78, at 209-10.

98 See Wilden, supra note 79 , at 242. 
As a meaning-endowing device, metonymy proceeds by establishing contextual relations along a syntagmatic axis. ${ }^{99}$ Thus, to metaphor's paradigmatic axis which can be regarded as a vertical axis, corresponds metonymy's syntagmatic axis which can be viewed as horizontal. ${ }^{100}$ Or to put it in another way, the opposition between metaphor and metonymy corresponds to the contrast between synchrony ("the axis of simultaneities") and diachrony ("the axis of successivities"). ${ }^{101}$

The metonymic function, like its metaphoric counterpart, also plays an important role in legal rhetoric and in constitutional discourse. At the most profound level, Lacan's notion of the metonymy of desire is reflected in the constitutional subject's above mentioned grasp of its identity as a lack. ${ }^{102}$ Inasmuch as the constitutional subject's search for identity is analogous to the metonymy of desire, the constitutional subject cannot fully overcome the experience of itself as (at least in part) a lack. Indeed, the metonymy of desire is ultimately animated by the desire of desire ${ }^{103}$ which can only be sustained so long as there remain objects of desire. ${ }^{104}$ Similarly, the constitutional subject could only fully overcome its lack if it became fully determined, or in Hegelian terms, if it became foritself what it is in-itself. Accordingly, the constitutional subject's lack is ultimately the unfulfilled desire for exhaustive determination. Such exhaustive determination, however, could only be realized as a consequence of full contextualization - that is, a synthesis of all past, present, and future instantiations of the place of the constitutional subject within the constitutional order. And that is, of course, impossible; not only because the future cannot be fully prophesied, but also because the past cannot be fully remembered.

In legal rhetoric, the metonymic function plays as important a role as the metaphoric function against which it is pitted. In the context of adversary proceedings, arguments stressing similarities are bound to be countered by arguments emphasizing differences. Legal arguments based on metonymy evoke differences by contextualizing, relying on relations of proximity to carve out a picture that reveals as many concrete details as possible. In common law

99 See JAKoBson, supra note 83 , at 70.

100 See Wilden, supra note 79, at 246.

$101 \mathrm{Id}$.

102 Id. at 242 .

103 Through an infinite series of objects which do not bring it satisfaction, desire, in the last analysis, aims at itself.

104 Indeed, desire can only maintain a relation to itself through the mediation of not-yetincorporated objects. 
jurisdictions, metonymic legal argument militates against the extension of precedent by contextualizing the relevant situations to the point that differences appear to far outweigh similarities. The rhetorical strategy of metonymic legal argument is to demonstrate that proposed analogies are besides the point. And taken to its logical extreme, metonymic legal argument would systematically undermine reliance on precedents, since upon being exhaustively contextualized every situation is ultimately unique.

The metonymic function also plays an important role in constitutional discourse since it figures in constitutional constructs, and contributes to the definition of constitutional rights and constitutional identity. The metonymic function pulls in the opposite direction of its metaphoric counterpart. At the level of constitutional arguments, metonymy leads to greater contextualization just as metaphor points to similarities. Moreover, as in metaphor, metonymy may be used to foster extension as well as constriction of constitutional rights, depending on the circumstances. Thus, for example, through metonymic contextualization, it becomes possible to surmount the colorblind hurdle in the pursuit of racial justice. ${ }^{105}$ Against Whites who seek to disadvantage African Americans because of their race, the colorblind principle remains a barrier. But such a barrier need not be made into an impediment against redressing the lingering injuries stemming from racism. ${ }^{106}$ Once the difference between healing the wounds of racism and further aggravating them is firmly in mind, rigid adherence to the principle of colorblindness seems both unnecessary and undesirable.

The use of metonymic contextualization to limit constitutional rights, on the other hand, is vividly illustrated by the majority and concurring opinions in Bowers $v$. Hardwick. As already mentioned, the Supreme Court's refusal to extend intimate association privacy rights to protect consensual homosexual sex, was sought to

105 But see Michel Rosenfeld, Decoding Richmond: Affirmative Action and the Elusive Meaning of Constitutional Equality, 87 MrCH. L. REv. 1729, 1761-62 (1989) (contrasting acontextual "atomistic mode of interpretation" with contextual "ecological mode of interpretation").

106 It is interesting, in this connection, to note that one of the frequent arguments against race-conscious policies designed to improve the plights of traditionally disadvantaged racial minorities is that once the colorblind barrier is lifted, even for a worthwhile purpose, there is no principled way to insure that racists will not take advantage of this development to better perpetuate their reprehensible aims. See, e.g., City of Richmond v. J.A. Croson Co., 488 U.S. 469 (1989). Underlying this line of argument may be a fear that left to their own devices people will be unable to properly contextualize issues regarding race. 
be justified by traditional repudiation through criminalization of homosexual acts and by hostility towards homosexuality rooted in the Judeo-Christian religious tradition. ${ }^{107}$ To combat the metaphor of the autonomous individual left alone to decide about his or her intimate associations with full responsibility and dignity, the Justices in the majority in Bowers chiefly resort to contextualization. Moreover, their metonymic contextualization is not confined to the circumstances surrounding the case ${ }^{108}$ but also encompasses the relationship between the case at hand and relevant precedents. In Griswold, the right of privacy was upheld in the context of the marital relationship. Through metonymic displacement, Griswold can be represented as a constitutional endorsement of the sanctity of the marital relationship; ${ }^{109}$ and thus, sharply contrasted with Bowers, which concerns homosexuality contextualized as abhorrent under Judeo-Christian canons of morality. Eisenstadt, however, cannot be subsumed under the sanctity of the marital relationship, as it explicitly extends rights to sexual intimacy to nonmarried individuals. Accordingly, to distinguish Bowers from Eisenstadt requires metonymic contextualization along other lines. Through metonymic displacement, Eisenstadt can be portrayed as a case about heterosexual, that is, "normal," sex which the Constitution protects among consenting adults. In contrast, by focusing on the long history of its criminalization, the majority in Bowers can present homosexual sex as "deviant" or "abnormal," and thus as distinguishable from the kind of sex afforded constitutional protection in Eisenstadt.

The metonymic function's contribution to the delimitation of constitutional rights becomes manifest in the implementation of such rights. In the abstract, everyone should enjoy the same equality or freedom-of-religion rights. In practice, however, such rights cannot be equally enjoyed unless they are properly tailored to the diverse needs and circumstances confronting their intended benefi-

107 Bowers v. Hardwick, 478 U.S. 186, 196 (1986).

108 In this connection, it is particularly noteworthy that the Court's majority departed from customary practice by interpreting the generally worded Georgia antisodomy statute applicable to heterosexuals as well as to homosexuals, exclusively in the context of its application to homosexuals. See Bowers, 478 U.S. at 190.

109 Further contextualization makes it ironic that Griswold could be viewed as promoting the "sanctity" of marriage, since Griswold affords married couples the constitutional right to use contraceptives-a right that is at odds with the "sanctity" of marriage as historically understood within much of the Judeo-Christian religious tradition. Metonymic contextualization, however, tends to be relative rather than absolute, and its precise limitations in a given case are likely to be determined by the aims and interests of its proponents. 
ciaries. To the extent that equality requires proportionality rather than mere similarity of treatment, it is necessary to contextualize and to take certain differences into account. Thus, for example, equality for women arguably involves more than being treated the same as men. Similarly, freedom to exercise one's religion requires contextualization since generally applicable laws may not have the same impact on different religious practices. A Sunday-closing law, for instance, is likely to be burdensome on sabbatarians inasmuch as it would force them to close their businesses for two days, whereas their competitors could close on only one day without violating their religious convictions. ${ }^{110}$

The metonymic process also contributes to the definition of the identity of the constitutional subject. Inasmuch as constitutionalism implies pluralism and heterogeneity, constitutional identity cannot be reduced to a mere relationship of similarity. Because constitutional identity must bridge a gap between self and other, it must incorporate differences through contextualization to avert subordination of some to others within the same constitutional regime. For example, in a multicultural or religiously pluralistic society, it is most unlikely that a positive identity that is neutral as between all cultural or religious groups could ever be achieved. ${ }^{111}$ Accordingly, taking certain differences into account may lead to a more satisfactory constitutional identity than simply glossing over them.

Metonymic influence on constitutional identity may on some occasions involve more than mere contextualization and amount to downright displacement. When a partial identity is too powerful to be successfully suppressed, yet too divisive to be openly and fully acknowledged, its impact may be masked through a focus upon contiguous partial identities. The American constitutional experience with the relation between the state and religion-or at least a plausible interpretation of that experience-provides an example of metonymic displacement as a means to bridge the gap between

110 But see Braunfeld v. Brown, 366 U.S. 599 (1961) (Sunday-closing law held not to violate Orthodox Jew's First Amendment right to freely exercise his religion).

111 See, e.g., Department of Human Resources v. Smith, 494 U.S. 872 (1990) (sacramental use of peyote not exempted from criminal prohibition); Reynolds v. United States, 98 U.S. 145 (1878) (criminalization of bigamy upheld notwithstanding Mormon claim that polygamy was a religious duty). In contrast, ritual use of wine by Catholics and Jews was exempted from prohibition mandated by the Eighteenth Amendment. See Board of Educ. v. Grumet, 114 S. Ct. 2481 (1994) (Kennedy, J., concurring) (referring to Prohibition exemption for use of alcoholic beverages for sacramental purposes). For a more systematic argument that abstraction beyond differences is not neutral, see ROSENFELD, supra note 15 , at 234-38. 
constitutional identity and the forces animating constitutional practice. From a cursory look at the Religion Clauses of the First Amendment, ${ }^{112}$ it would appear that the state should maintain a completely neutral stance towards religion. On the one hand, the state should do nothing to promote religion; on the other, it should do nothing that would interfere with its citizens' freedom to practice the religion of their choice. ${ }^{113}$ Accordingly, whereas Americans may be by and large a religious people, ${ }^{114}$ their constitutional identity would appear to be one of neutrality, fairness, and equanimity towards religion. Based on a consideration of relevant practices and the Supreme Court's jurisprudence regarding the Religion Clauses, however, it is certainly a plausible conclusion that American constitutional identity is at bottom predicated on endorsement of a particular religion-or more precisely, a particular brand of religion - to the detriment of other religions.

Although the Supreme Court's Religion Clauses jurisprudence has been subject to fluctuations, ${ }^{115}$ overall, and when taken in conjunction with prevalent institutional practices, it is arguably best understood as an endorsement of a moderate mainstream, mainly Christian, brand of religion. This endorsement, moreover, militates against, on the one hand, atheism, and on the other, more fundamentalist brands of Christianity; and, against other religions removed altogether from the Judeo-Christian tradition, such as Native American religions. ${ }^{116}$

The most ubiquitous and powerful metaphor, in the Religion Clauses, is that of the "wall of separation" between church and

112 The First Amendment provides in relevant part that "Congress shall make no law respecting an establishment of religion, or prohibiting the free exercise thereof." U.S. Const, amend. I. These two clauses are referred to respectively as the "Establishment Clause" and the "Free Exercise Clause."

113 Although the Religion Clauses of the First Amendment were originally only applicable to the federal government, see Barron v. Mayor and City Council of Baltimore, 32 U.S. 243 (1833), they have now been made applicable to the states by incorporation through the Fourteenth Amendment, see Everson v. Board of Educ., 330 U.S. 1 (1947) (Establishment Clause applicable to states); Cantwell v. Connecticut, 310 U.S. 296 (1940) (Free Execise Clause applicable to states).

114 See Lynch v. Donnelly, 465 U.S. 668, 674 (1984) (stressing historical role of religion in the United States); Zorach v. Clauson, 343 U.S. 306, 313 (1952) (Americans are a religious people); Note, Developments in the Law-Religion and the State, 100 HARV. L. REv. $1606,1612-13$ (1987) (95\% of Americans believe in God and 60\% belong to some religious organization).

115 See David FeIsen, Comment, Developments in Approaches to Establishment Clause Analysis: Consistency for the Future, 38 AM. U. L. Rev. 395 (1989).

116 See Timothy L. Fort, The Free Exercise Rights of Native Americans and the Prospects for a Conservative Jurisprudence Protecting the Rights of Minorities, 23 N.M. L. REv. 187 (1993). 
state. ${ }^{117}$ And the most controverted public debate concerning the Religion Clauses is whether this "wall" should guarantee complete separation between church and state, or whether it should be lowered to permit state aid to religion so long as the state refrains from officially endorsing any particular religion. ${ }^{118}$ This debate, however, conceals the dominant constitutional identity that emerges from institutional practices and Supreme Court opinions on the Religion Clauses.

The official endorsement of mainstream religion is effectuated through several different practices and discursive processes, among which metonymy plays a limited but crucial role. Official endorsement of God against atheists is prevalent in institutional practices, such as, the recitation of prayers by official chaplains at the opening of a legislative session;,119 or the printing of "In God We Trust" on official paper and coin currency; or the statement by a Supreme Court Justice, in the course of an Establishment Clause opinion, endorsing belief in a "Supreme Being." the Supreme Court has upheld a congressional statute exempting from combat, conscientious objectors opposed to "war in any form" because of their "religious training and belief"- "belief" being defined as a "belief in a relation to a Supreme Being involving duties superior from those arising from any human relation, but [not including] essentially political, sociological, or philosophical views or a merely personal moral code."121 Taken together, these developments unmistakably point to a constitutional identity that is not neutral on questions of religion, but rather biased in favor of broad theistic views, at least as against atheistic or agnostic views.

The constitutional bias in favor of mainstream religion to the detriment of other religious practices emerges, on the other hand, from the Supreme Court's Free Exercise Clause jurisprudence. This bias is reflected in the Court's general tendency to refuse exemptions from generally applicable laws for practices such as po-

117 See Reynolds v. United States, 98 U.S. 145, 164 (1879) (citing Thomas Jefferson).

118 See Laurence H. Tribe, American Constitutional Law $\$ 14-4$, at 1166-68 (2d ed. 1988).

119 Marsh v. Chambers, 463 U.S. 783 (1983).

120 Zorach v. Clauson, 343 U.S. 306, 313 (1952).

121 United States v. Seeger, 380 U.S. 163, 165 (1965) (upholding $\S 6(j)$ of the Universal Military Training and Service Act, 50 U.S.C. App. $\$ 456(j)$ (1958), though broadly interpreted). Statutory reference to a "belief in a relation to a Supreme Being" was deleted in a 1967 amendment to 6(j). Nonetheless, the statute still precludes exempting an avowed atheist claiming an exemption on purely moral grounds. But see Justice Black's plurality opinion in Welsh v. United States, 398 U.S. 333 (1970), reading the relevant statutory language so broadly as to blur the distinction between religious and nonreligious ethical views. 
lygamy ${ }^{122}$ or ritual use of peyote, ${ }^{123}$ which are repugnant to mainstream religion or to the mores of the majority. Finally, both the bias against atheists and that against nonmainstream religion underlie recent Supreme Court Establishment Clause jurisprudence, most notably the 1984 decision in Lynch $v$. Donnely. ${ }^{124}$ In Lynch, the Court upheld a city's Christmas display that included a crèche, located at the heart of the shopping district, as not violative of the Establishment Clause. To reach this result, the Court had to overcome two doctrinal hurdles: it had to find that there was a secular purpose to the display of the crèche, and it had to conclude that the display did not amount to an official endorsement of religion by the city. ${ }^{125}$ Since the crèche depicts the nativity scene, which is of profound religious significance to Christians but not to those who adhere to other faiths, such as Judaism, the hurdles confronting the Court's five-four majority seemed rather formidable. Nevertheless, through a combination of negation and metonymic displacement, the Court managed to decide that public display of the crèche amounted to neither a lack of secular purpose nor an official endorsement of (a particular) religion. As against atheists and advocates of rigid separation between church and state, the majority Justices argued that display of the crèche did not endorse any particular religion any more than generally accepted practices, such as printing "In God We Trust" on coins. ${ }^{126}$ As against both non-Christians and Christians for whom the crèche evokes strong religious convictions, the Court's majority trivialized the crèche, by stressing its display in the context of commercial and other national secular traditions now associated with the Christmas holiday. ${ }^{127}$

From the perspective of atheists or rigorous separationists, Lynch is an impermissible endorsement of religion. From the per-

122 See Reynolds v. United States, 98 U.S. 145 (1879).

123 See Department of Human Resources v. Smith, 494 U.S. 872 (1990).

124465 U.S. 668 (1984).

125 Id. at 679. In Lemon v. Kurtzman, 403 U.S. 602, 612-13 (1971), the Supreme Court adopted a three-pronged test applicable in Establishment Clause cases: first, the law must have a secular legislative purpose; second, its principal or primary effect must be one that neither advances nor inhibits religion; and, third, it must not foster "an excessive government entanglement with religion." The Court in Lynch, however, was unwilling to be confined to any single test. Subsequent to Lynch, the Court has not consistently followed the Lemon test, but it has not repudiated it. See Lee v. Weisman, 112 S. Ct. 2649 (1992); Ruti Teitel, A Critique of Religion as Politics in the Public Sphere, 78 Cornell L. Rev. 747, 769 \& n.76 (1993).

126 See Lynch, 465 U.S. at 676.

127 In the words of Justice O'Connor, the "crèche is a traditional symbol of the holiday that is very commonly displayed along with purely secular symbols, as it was in Pawtucket." Id. at 692 (O'Connor, J., concurring). 
spective of a profoundly committed Christian, on the other hand, Lynch represents a trivialization of religion and an ultimate surrender to secularism. ${ }^{128}$ By nurturing the antagonism between these two entrenched positions, the Court's majority in Lynch manages to promote mainstream religion through a double displacement that may appear to be an effort to appease both sets of antagonists. Indeed, mainstream religion is contiguous to both separationists, on one side, and to those who are profoundly religious, on the other. Accordingly, both the holding in Lynch and the American constitutional approach to the relation between state and religion can be metonymically portrayed as carving a nonreligiously motivated, and predominantly neutral, middle course between ardent secularists and profoundly committed adherents to religion; when, at bottom, they promote a particular brand of religion which is neither neutral, nor heterogeneous. Consistent with this, metonymic displacement enables a constitutional identity shaped by mainstream religion to remain hidden behind a mask of fairness and neutrality toward religion(s). ${ }^{129}$

\section{Reconstructive Constitutional Discourse and the Relation Between Negation, Metaphor, and Metonymy}

The preceding discussion of negation, metaphor, and metonymy reveals the complexity of the discursive processes associated with the reconstructive search for constitutional identity. This complexity is compounded when one considers the ways in which negation, metaphor, and metonymy operate while they interact. Indeed, such interaction not only modifies and delimits the ways in which these three discursive devices combine to project images of constitutional identity; it also shapes the elements slated to become building blocks in the (re)construction of constitutional identity. To illustrate this, we need only briefly return to the double displacement whereby an image of constitutional identity as it relates to religion is structured in Lynch. ${ }^{130}$ This double displacement can only succeed in fostering state endorsement of mainstream religion

128 An adherent to a non-Christian religion could either side with the separationist if he or she most fears state favoritism towards Christianity, or with the profoundly committed Christian if his or her greatest concern is surrender to secularism and trivialization of religion.

129 By including both the singular and the plural, I mean to emphasize the dual possibility of strict separation between church and state-which can inure to the benefit of both secularists and adherents to religion-and the state's equally active promotion of all religions - which may be to the equal benefit of mainstream and nonmainstream religions, but which is to the detriment of atheists and agnostics.

130 See Lynch, 465 U.S. at 668. 
as benevolent neutrality towards religion, if the crèche can plausibly be depicted as sufficiently detached from its origins in a purely religious context to stand for something other than a transparent endorsement of Christian religion. Consistent with this, the majority in Lynch used both metaphoric and metonymic arguments to establish that the crèche at stake in that case was, at least in part, severed from purely religious concerns. Through metaphoric analogy, display of the crèche was equated to exhibiting paintings depicting a religious subject matter as part of the collection of a stateowned museum. ${ }^{131}$ Through metonymic focus on contiguity and context, on the other hand, the location of the crèche next to less, or nonreligious, Christmas symbols in the context of the dominant commercial pursuits associated with shopping centers, was meant to suggest that the principal motivation for the display of the crèche was commercial rather than religious. ${ }^{132}$ As this example indicates, interaction between negation, metaphor, and metonymy occurs at many different levels resulting in multiple combinations and intersections, which would have to be successfully integrated to present an exhaustive account of the reconstructive formation, evolution, and dissolution of constitutional identities.

It is beyond the scope of the present undertaking to attempt any comprehensive account of the intricate ways in which negation, metaphor, and metonymy actually combine in the course of the reconstructions of constitutional identity. Instead, I will concentrate on the most salient aspects of the interaction between the three above mentioned devices in relation to the determination of constitutional identity as a whole, without special regard to how the individual elements involved are themselves derived. From such an overall standpoint, negation-particularly through determination, repression, and renunciation-assumes the principal role in carving out the identity of the constitutional subject, with metaphor and metonymy fulfilling the important task of providing content to the respective roles of identity and difference. Indeed, negation delimits the constitutional subject by mediating between identity and difference. But only through the work of metaphor and metonymy can identity and difference acquire determinate forms. In other words, only metaphor and metonymy will reveal which identityor, more precisely, identities-and which difference-or differences-ought to be mediated through negation to yield a plausible reconstruction of a suitable constitutional subject.

131465 U.S. at $676-77,683$.

132465 U.S. at $671,685$. 
The function of metaphor and metonymy in delimiting constitutional identity must be understood in terms of the previously discussed overall role played by negation in the definition of the constitutional subject. ${ }^{133}$ By upsetting the status quo and uprooting settled meanings, negation creates a vacuum which must be filled through the pursuit of equivalent meanings along the paradigmatic axis, and contiguous meanings along the syntagmatic axis. The replacement of uprooted meanings, moreover, requires a concurrent journey along both these axes, as all meanings hinge on relations of similarity as well as on relations of contiguity. Thus, constitutional meaning and identity depend on establishing coordinates along the syntagmatic and paradigmatic axes. In order to understand how reconstruction of the constitutional subject's identity works, therefore, it is necessary to take a closer look at the relationship between metaphor and metonymy, and, in particular, at how interaction between the two results in securing determinate coordinates along the paradigmatic and syntagmatic axes.

As already mentioned, metaphor functions by setting relations with reference to a code, whereas metonymy does the same with reference to a context. ${ }^{134}$ Neither metaphor, standing alone, nor metonymy, completely cut loose from any code can generate any coherent meaning. In other words, for meaning to be produced, the semantic path made up of metaphoric relations must intersect with its counterpart built on metonymic relations. Indeed, journeying along the metaphoric path can be analogized to attempting to ascertain the meaning by exclusive reference to a dictionary. Assuming no reference whatsoever to any context, reliance on the dictionary proves completely circular. Each term would have to be defined by other terms, with the original term sought to be defined eventually figuring in the definition, thus referring back to itself. On the other hand, should the syntagmatic relations along the metonymic path be considered completely separately from any paradigmatic relations, it would also be impossible to generate any coherent meaning as each term within a sequence would lead to the next term within the same sequence, without ever acquiring an identity of its own. ${ }^{135}$ It would be as if one became familiar with a set sequence of words in a completely foreign language. After a

\footnotetext{
133 See supra part III.A.

134 See supra III.B-C.

135 As noted by Jakobson, in aphasia leading to destruction of the capacity to establish relations along the paradigmatic axis, terms tend to become perceived exclusively in terms of their syntagmatic relations, thus making it impossible to name things. ROMAN JAKOBson, EsSAis de LiNGUistiQue Génerale 54 (1973).
} 
while, upon reading the first word in the sequence, one would be able to recite the rest of the sequence in its proper order, but without thereby being in any better position to understand the meaning of the sequence.

Notwithstanding that meaning requires reference to both the metaphoric and the metonymic paths, particular utterances may rely on a preponderance of either metaphoric or metonymic relations. ${ }^{136}$ Depending on differences in personality, culture, and style, metaphoric or metonymic processes may gain the upper hand. ${ }^{137}$ Moreover, as already mentioned, in the realm of legal argumentation, tilts towards metaphoric or metonymic processes are to an important degree determined by stakes in the legal outcomes; with those wishing to extend application of an existing legal norm relying on metaphor, while those seeking to contain the spread of such norm, appealing to metonymy. ${ }^{138}$

At the more global level of the formation and evolution of constitutional identities, metaphoric processes are intertwined with metonymic ones in an ongoing dialectic. At the highest level of abstraction, this dialectic confronts the challenge of projecting an identity lending support to the perception that the same constitution endures through the generations, stretching back to that of the constitution makers. At the more concrete level of particular constitutional rights, moreover, this dialectic strives to promote an equilibrium between the pole of identity and the contrary pole of difference. This is perhaps best illustrated by reference to constitutional rights to equality.

Viewed from a formal standpoint, constitutional equality requires properly accounting for relevant identities and relevant differences. ${ }^{139}$ Consistent with this, ideal constitutional equality would fully account for, and optimally integrate, all relevant identities and differences. Practically, however, the relevance of identities and differences will be contested. Moreover, this problem is

136 See id. at 61.

137 Id. Jakobson points out that when children are given a name and asked for a verbal reaction, they invariably react in one of two ways: they either utter a verbal expression linked to the name in question by a relation of similarity, or else, by a relation of contiguity. Id. Thus, for example, confronted with the term "ice cream," a child may be more drawn towards metaphoric processes and answer "cake," or be inclined towards metonymic processes and respond "summer."

138 See id.

139 For example, the colorblind principle can be regarded as premised on the belief that racial differences are irrelevant for purposes of constitutional equality, or on the belief that beyond racial differences, there is an identity shared by all human beings that is relevant for purposes of constitutional equality. 
compounded to the extent that identities and differences are not simply given, but rather constructed. ${ }^{140}$ Finally, given the logic of the dialectic between identity and difference, both identity and difference can be invoked, depending on the circumstances, either to make equality rights more inclusive or more exclusive. For example, against the background of African American slavery, stress on the metaphoric process that leads to an identity beyond race seems bound to result in a more inclusive conception of constitutional equality. ${ }^{141}$ By contrast, in a polity divided into a majority and a minority linguistic group, identity in disregard of linguistic differences practically resulting in advantages for members of the linguistic majority, would lead to a relatively more exclusive conception of constitutional equality. ${ }^{142}$ On the other hand, it is obvious that stress on metonymic process to highlight difference can serve the purposes of restricting the scope of constitutional equality. Thus, differences relating to gender have been used to deny women equality. ${ }^{143}$ Less obvious, perhaps, is that emphasis on differences can also go hand in hand with efforts to expand the scope of equality rights. As examples, one can mention equal catering to the different needs of men and women, or of diverse linguistic groups.

In general, the evolution of equality rights can be reconstructed as comprising three different stages. The first of these is marked by a strong emphasis on the correlation between inequality and difference. Moreover, such correlation may be projected back into a preconstitutional past-such as prerevolutionary feudalism-or derived metonymically in contrast to a purely formal equation of equality to identity. ${ }^{144}$ The second stage is dominated by the correlation between identity and equality, and is reached through heavy reliance on metaphoric processes. The evolution from the first to the second stage is marked by the passage from

140 See, e.g., Patricia A. Cain, Feminist Legal Scholarship, 77 Iowa L. Rev. 19 (1991).

141 Compare the majority opinion in Plessy v. Ferguson (racial apartheid held consistent with Equal Protection Clause of the Fourteenth Amendment) with Justice Harlan's dissenting opinion (consistent with the color-blind principle, racial apartheid should be deemed unconstitutional).

142 Thus, if all government business must be conducted in the majority language, equal opportunity to compete for government employment may in fact result in a disadvantage for speakers of the minority language.

143 See, e.g., Bradwell v. State, 83 U.S. 130 (1873) (state denial of right to practice law to women held constitutional and justified in terms of women's role as wife and mother).

144 Good examples in the American case include the treatment of African American slaves in the context of formal adherence to the proposition that "all men are created equal," and the treatment of women even after adoption of the Fourteenth Amendment as illustrated by the Bradwell case. 
race-based subordination to colorblindness, and from the tutelage of women to equality between the sexes regardless of gender differences. Finally, the third stage is marked by a more encompassing and finely tuned equality that accounts for differences without exploiting them to institute patterns of domination or subordination. Typical of this third stage would be equality based on the slogan, "to each according to his or her (different) needs." Thus, for instance, a woman's constitutional right to have an abortion could be justified as a third stage equality right. Based on a second stage conception of equality, men and women should have the same control over their body. But further contextualization, through a metonymic chain of thoughts, leads to the conclusion that for a woman's control over her body to be comparable to a man's over his, requires awarding her certain different rights, including the right to abortion.

Passage through contextualization from second stage equality as identity, to third stage equality as difference depends for its success on simultaneous preservation and transcendence of certain key identities, consistent with Hegel's concept of Aufhebung. ${ }^{145}$ Accordingly, the metonymic process leading to equality as difference can move away from the metaphoric identity that locks in second stage equality, but only so far as it does not altogether lose sight of that identity; or, put in another way, so long as it does not stray from the sphere of influence circumscribed by the identity in question. In short, equality as difference hinges on mutual influence of determinate forms of metaphoric identity and metonymic difference. Once the delicate balance between those determinate forms pulling in opposing directions is upset, however, the movement from identity to difference seems more likely to regress towards first stage equality where difference is paired with inequality, rather than to advance towards third stage equality as difference. ${ }^{146}$ Thus, whereas the interplay between metaphor and metonymy plays an essential role in the progression through the three stages of equality, every step must be measured to balance metaphor and metonymy so as to avoid the twin dangers of overly restrictive identity and insufficiently constrained difference.

145 See supra part III.A.

146 For example, if contextualization of the plight of women confronting unwanted pregnancies is pushed to the point that the basic identity between men and women slips beyond the horizon, differences-and particularly those that relate to the presence and the potential life of the fetus-may well lead to a denial of abortion rights, and hence of full equality rights to women. 
Granted that developments along the metaphoric path must be correlated to those along the metonymic path, the question remains how trajectories along both these paths can be reined in so as to single out identities and differences best suited to reconcile the self and other within the constitutional subject. In other words, all the terms susceptible of substitution along the metaphoric path have the same exchange value, and the question is, what makes some of these terms have greater use value than others? For their part, all terms along the metonymic path relate to one another in terms of contiguity, and the question becomes, what determines the location of meaning-endowing pauses which render metonymic sequences intelligible? Or, put somewhat differently, what accounts for the punctuation which endows sequences of contiguous terms with determinate meaning?

The selection of particular identities and differences to figure in a given project of constitutional reconstruction is a function of the confluence of structural constraints imposed by the constitutional order, and of the sociocultural heritage of the relevant polity. These structural constraints account for the establishment of a plausible constitutional identity depending on the production of a meaningful narrative through negation, substitution (metaphor), and displacement (metonymy). The sociocultural heritage, on the other hand, furnishes the material which must be reshaped through negation, metaphor, and metonymy; in such a way as to promote both links to, and contrasts with, the preconstitutional and the extraconstitutional self.

To understand how negation, metaphor, and metonymy combine to reshape materials drawn from the sociocultural heritage of the polity into a constitutional identity, it is necessary to first briefly consider the role of constitutional law in a democratic legal order. Even in a democracy, law looms as an alienating intrusion of the other upon the self. Law is by and large experienced as coercive, and submission to its edicts can be likened to bowing to the constraints devised by the superego. ${ }^{147}$ Notwithstanding a law's democratic enactment, and one's support of such enactment, that law's application imposes external constraints on all those who come within its sweep. ${ }^{148}$ Inasmuch as constitutional law is law,

147 See LACAN, supra note 1 , at 130.

148 Even if one agrees with Rousseau that each member of a democratic polity is at once an integral part of the sovereign who enacts laws conforming to the general will, and an individual who is obligated to obey such laws, see RoussEAU, supra note 17, at 16-18, there still seems to be an insurmountable split between these two roles which makes the obligation to obey the law both constraining and alienating, see Rosenfeld, supra note 17, at 868 . 
moreover, it is also constraining and alienating. Inasmuch, however, as constitutional law can be invoked to counter or set aside coercive democratically enacted laws, it also contributes to selfaffirmation and to emancipation. ${ }^{149}$

In the last analysis, both the self whose self-affirmation and emancipation are promoted by constitutional law, and the other who pursues self-affirmation through majority backed legislation are meant to be included in the constitutional subject. Accordingly, besides being constraining qua law, the constitution is at once constraining and emancipatory: it constrains all those who come within its sweep as members of the legislating sovereign; and it contributes to the emancipation of the members of the very same group, to the extent that they become obligated to abide by the dictates of duly enacted laws. Consistent with this, moreover, negation, metaphor, and metonymy must combine to reshape materials issued from the sociocultural heritage of the relevant polity so as to construct a constitutional identity at once suited to the constraining and to the emancipatory role of constitutional law.

Remembering that from any given (partial) perspective at any given time and place, constitutional identity emerges predominantly as a lack; negation, metaphor, and metonymy must combine to deal with available materials with a view to overcoming that lack. The precise contours of any particular historically situated lack, depend, however, on the prevailing circumstances. For example, if the grip of a society's sociocultural heritage is too tight, no space may be left for a positive constitutional identity, with the consequence that the first step towards overcoming such lack (of space) would have to consist in negation of (at least part of) the omnipresent sociocultural heritage. If, on the contrary, repudiation of such heritage has been so thorough and systematic that the space for constitutional identity is more than adequate but completely barren, then overcoming the lack would require developing new materials or reincorporating previously discarded ones. But such reincorporation could not be made wholesale, for that would undermine rather than further the quest to overcome the lack within the constitutional subject. Hence, reincorporation may be

Indeed, in Rousseau's own famous words, "whoever refuses to obey the general will shall be compelled to it by the whole body: this in fact only forces him to be free." RoussEAu, supra note 17 , at 18 . Needless to say, legislative minorities subjected to laws which they have opposed are even more clearly subjected to onerous external impositions.

149 The most obvious example of the emancipatory potential of constitutional law is furnished by the protection of fundamental rights. Thus, freedom of expression protects against submission to majority views. 
viewed as a process involving the return of the repressed, ${ }^{150}$ and calling for the deployment of metaphor and metonymy. More precisely, for its return to be successful, the repressed must become sufficiently transformed to endow the constitutional subject with elements of a positive identity, by establishing connections between discarded past materials and new materials through a series of substitutions and displacements.

As constitutional identity must promote reconciliation or equilibrium between self and other; identity and difference; constraint and emancipation; sociocultural heritage and sociocultural renewal or reinvention; the most privileged points along the metaphoric and the metonymic paths are likely to be those best suited-in terms of the particular circumstances involved-to advance most, if not all, of these objectives. Thus, it is overdetermination as understood in Freudian theory, ${ }^{151}$ which lays down the landmarks along the metaphoric and the metonymic paths in constitutional identity. According to Freud, a particular dream-image or symptom is likely to be the product of a confluence of different causes. Freud gives the example of a woman prone to hysterical vomiting, a symptom that provided an (albeit unconscious) expressive outlet to contradictory wishes. ${ }^{152}$ One of this woman's wishes was to become impregnated as often as possible by as many men as possible; the other, was the punitive counterwish to be so unattractive that no man would have any desire for her. Vomiting, moreover, came to symbolize both these contradictory wishes through substitution and displacement. Along the metaphoric path, vomiting became a substitute for unattractiveness; along the metonymic path, on the other hand, vomiting displaced pregnancy (with which it is closely associated through morning sickness). Vomiting could thus stand out as a hinge linking together the two contradictory wishes along both the metaphoric and metonymic paths. Given its metaphoric and metonymic coordinates, vomiting provided these contradictory wishes with an expressive outlet that remained inaccessible to the woman's consciousness. In short, the confluence of all these factors overdetermined vomiting as a suitable symbolic vehicle for the expression of the woman's contradictory unconscious desires.

150 See Sigmund Freud, Repression (Cecil M. Baines trans.) (1915), reprinted in General Psychological Theory: Papers on Metapsychology 104 (Philip Rieff ed., Collier Books 1970).

151 See FreUD, supra note 78, at 341-43, 517-18.

152 Id, at 609 . 
Returning to the constitutional setting, the use of tradition in American Due Process jurisprudence provides a good example of the role of overdetermination in shaping constitutional meaning. I have already alluded to the metonymic uses of tradition in the Supreme Court's decision in Bowers v. Hardwick. ${ }^{153}$ Viewed from a broader perspective, however, tradition's Due Process role is not merely metonymic. Rather, as a consequence of overdetermination, tradition emerges as a particularly well-suited semantic vehicle to bind together various symbolic strands extracted respectively through negation, metaphor, and metonymy. As we shall see, tradition can at once serve to make negation determinate, and to frame suitable coordinates along the metaphoric and metonymic axes.

As already mentioned, tradition is important in all modern constitutional settings, as it is bound to figure prominently in the crucial relationship between the preconstitutional and the constitutional self. ${ }^{154}$ Moreover, whereas no constitutional regime can completely do away with tradition, one can distinguish generally between two different approaches: engrafting a set of constitutional norms on an ongoing tradition; or, replacing the order framed by tradition with a new order defined by the constitution. Although, as noted above, the United States Constitution did not attempt a complete break with preexisting tradition, ${ }^{155}$ it certainly provides a clear example of the second of these approaches. Indeed, in the United States, the Constitution forms the centerpiece of national identity rather than one among many equally, or more, important attributes of national identity. ${ }^{156}$ This is not surprising, since as a nation built upon successive waves of immigration, the United States encompasses a wide diversity of national and ethnic traditions, none of which are representative of the polity as a whole. Thus, whereas it is not difficult to visualize French or German identity without reference to their respective constitutions, the same would not apply to the United States.

To the extent that the United States Constitution is set against tradition-or, in other words, is the tradition-it needs to reincorporate rejected traditions in developing a positive identity. Thus, whereas negation of tradition is constitutive of not only

153 See supra part III.C.

154 See supra part II.A.

155 See supra notes $42-46$ and accompanying text.

156 See Gary J. Jacobsohn, Apple of Gold: Constitutionalism in IsRael and the United States 9, 109 (1993). 
American constitutional identity, but also of American national identity; the negation of this negation-in the form of reintegration of elements of the rejected tradition-likewise forms an integral part of the (re)construction of the identity of the constitutional subject. Moreover, the negation of tradition, and the negation of this negation represent two distinct, successive, logical moments within a scheme of dialectical reconstruction. But, it does not follow from this that the two cannot operate simultaneously within the time frame delimited by a particular constitutional practice. Actually, at least in some cases, the two must operate simultaneously, which requires that coherent constitutional meaning be extracted from contradictory drives. This, in turn, is made possible by distancing the tradition to be reincorporated from the discarded tradition through substitution and displacement.

What is particularly remarkable about the American Due Process jurisprudence as it pertains to liberty rights is that tradition itself has come to occupy, through overdetermination, the place of both countertraditional constitutional negation, and neotraditional negation of the negation. Constitutional liberty rights are fundamentally countertraditional, inasmuch as claims to liberty in a democratic polity amount to assertions of entitlement to deviate from majority backed norms and values. ${ }^{157}$ Constitutional liberty, however, cannot be unlimited for that would undermine the very notion of constitutional order. Accordingly, constitutional liberty is necessarily subject to certain constraints, and these constraints are of primarily two kinds: structural constraints inherent in constitutionalism and the constitutional order, ${ }^{158}$ and constraints derived from the sociocultural heritage of the polity. ${ }^{159}$

Due Process liberty rights are particularly open-ended since they are stated in such broad and general terms as to leave ample

157 Thus, for example, in a democracy, freedom of speech is much less necessary to protect the views of the majority than the views that the majority reject as unworthy or repugnant.

158 For example, constitutional democracy depends on protection of freedom of expression rights, because uninhibited expression of minority views plays an important role in the legitimation of majority rule. How far such rights should extend, however, is problematic as it is unclear whether unlimited protection of extremist speech ultimately promotes or inhibits constitutional democracy. See Michel Rosenfeld, Extremist Speech and the Paradox of Tolerance, 100 Harv. L. Rev. 1457 (1987) (reviewing Lee C. Bollinger, The Tolerant Society: Freedom of Speech and Extremist Speech IN America (1986)).

159 For example, arguably, constitutionalism is compatible both with a constitutionalized liberty that encompasses polygamy and with one that does not, at least so long as claims to entitlement to polygamy are not predicated on religious grounds. Accordingly, the determination of whether constitutional liberty should include a right to choose polygamy would have to rely on the relevant sociocultural heritage. 
room for diverse, and even contradictory, interpretations. Thus, Due Process liberty has been interpreted variously as being procedural rather than substantive; ${ }^{160}$ as encompassing substantive economic liberty rights ${ }^{161}$ and, as encompassing substantive personal liberty rights relating, among others, to marriage, procreation, and intimate associations. ${ }^{162}$ Consistent with this, the identity of liberty rights under the Due Process Clause can be said, quite literally, to amount to a lack only susceptible of determinate content through reconstruction. ${ }^{163}$

To illustrate how tradition factors into dealing with the lack circumscribed by the Due Process Clause, let us take a closer look at reconstructions of liberty rights as substantive, in relationships of intimate association. As already pointed out, the Supreme Court invoked tradition to uphold liberty and privacy rights within the marital relationship in the face of a state's prohibition against the use of contraceptives in Griswold $\nu$. Connecticut. ${ }^{164}$ Viewed closely, however, the invocation of tradition to strike down a prohibition against contraceptives as unconstitutional is quite problematic. On the one hand, the very constitutionalization of liberty and privacy interests is to an important degree countertraditional. Indeed, even if these interests were actually protected in the preconstitutional polity, their constitutionalization transported them onto a whole new plane. Prior to constitutionalization, these interests were prey to religious traditions, historically rooted mores, the will of political majorities, or the edicts of a monarch. After constitutionalization, in contrast, these interests become severed from all these dependencies; thus, standing in opposition to their roots in tradition. In short, even if they can be traced back to tradition, but for the negation of such tradition, the liberty and privacy interests in question could not acquire a meaningful constitutional dimension.

On the other hand, the neotraditional aspect of the liberty and privacy interests vindicated in Griswold is also quite problematic.

160 See, e.g., Nebbia v. New York, 291 U.S. 502 (1934).

161 See, e.g., Lochner v. New York, 198 U.S. 45 (1905).

162 See, e.g., Moore v. City of East Cleveland, 431 U.S. 494 (1977); Roe v. Wade, 410 U.S. 113 (1973); Eisenstadt v. Baird, 401 U.S. 934 (1972); Griswold v. Connecticut, 381 U.S. 479 (1965).

163 Rarely, if ever, is a constitutional provision stated with such precision as to preclude further determination through reconstructive interpretation. Nevertheless, the range and scope of interpretive possibilities left by the Due Process Clause is singularly vast. Indeed, whereas more narrowly drawn constitutional provisions may call for reconstruction at the margins, the Due Process Clause requires reconstruction to acquire a core identity.

164381 U.S. at 486. 
The specific liberty and privacy interest recognized as constitutionally protected in Griswold is the right of a married couple to use contraceptives. But, as already pointed out, this is not a traditionally protected interest. ${ }^{165}$ Actually, it would undoubtedly shock a vast majority of our preconstitutional ancestors who were deeply steeped in the Judeo-Christian tradition to learn that uninhibited use of contraceptives, even if only within the marital relationship, should be considered as an integral part of that tradition.

Tradition does occupy a central position in the constitutional jurisprudence articulated in Griswold, but it is by no means a simple or straightforward one. In its projection towards the past, Griswold, in fact negates (by constitutionalizing) a tradition that was; in its projection towards the future - that is, a future at least from the vantage point of the constitution-making generation-by contrast, Griswold makes into a tradition something that was not. Moreover, to understand how tradition can come to symbolize simultaneously both the uprooting of established traditions and the invention of new ones, it is necessary to take a closer look at the workings of metaphor and metonymy in the Supreme Court's Due Process liberty jurisprudence.

The metaphoric and metonymic connotations of tradition become evident in the debate over the appropriate level of abstraction at which a tradition may be appropriated to sustain the constitutionalization of a particular liberty interest. This debate sharply divided the Justices in Michael H. v. Gerald $D .{ }^{166}$ In that case, a genetic father demanded visitation rights to see his child notwithstanding a state statute that established a conclusive presumption that a child born to a woman living with her husband is a child of the marriage. In a closely divided decision, the Supreme Court refused to recognize a constitutional right to visitation for genetic fathers under the circumstances of the case. Writing for a plurality, Justice Scalia declared that a relevant tradition had to be taken at "the most specific level," 167 and since he could find no tradition affording out-of-wedlock fathers visitation rights to see their illegitimate children, recognizing a constitutionally protected liberty right under the circumstances was unwarranted. ${ }^{168}$

Justice Brennan, however, took sharp issue with Justice Scalia's approach, noting that it deprived the notion of tradition of

\footnotetext{
165 See supra note 109 and accompanying text.

166491 U.S. 110 (1989).

167 Id. at 128 n. 6.

$168 \mathrm{Id}$. at 127 .
} 
any independent constitutional meaning. Indeed, in Justice Brennan's view, the only traditions that would be vindicated under Justice Scalia's criterion would be those already protected by legislative majorities, for which constitutional protection would be merely redundant. ${ }^{169}$ Instead, Justice Brennan indicated that the relevant interest involved in the case was "that of a parent and child in their relationship with each other", ${ }^{170}$ thus, construing the "tradition" at a relatively high level of abstraction, which made his proposed constitutionalization of the liberty interest involved far from superfluous. In direct response to Justice Scalia, moreover, Justice Brennan argued that:

the plurality ignores the kind of society in which our Constitution exists. We are not an assimilative, homogeneous society, but a facilitative pluralistic one .... Even if we can agree ... that "family" and "parenthood" are part of the good life, it is absurd to assume that we can agree on the content of those terms and destructive to pretend that we do. In a community such as ours, "liberty" must include the freedom not to conform..$^{171}$

Embedded, therefore, in Justice Brennan's abstract notion of tradition, is the "tradition" not to conform to tradition; or in other words, countertradition as a constitutional (as opposed to a preconstitutional) "tradition."

Justice Scalia's approach is predominantly metonymic, whereas Justice Brennan's is above all metaphoric. Indeed, Justice Scalia contextualizes the disputed liberty interest, and by refusing to draw more general and more abstract inferences from the invoked tradition, he exalts context and contiguity at the expense of parallels and similarities. Overemphasis along the metonymic path, however, not only makes the constitutionalization of tradition ultimately pointless, but also eventually undermines the very concept of tradition. In the quest for utmost specificity, every occurrence would be given such an exhaustive specification, that no two contiguous occurrences could ever emerge as continuous, thus undermining the very basis upon which the possibility of building any tradition rests. Or, to put it somewhat differently, if all the differences, no matter how minute, between two occurrences had to be unearthed; it would become increasingly difficult to perceive

169 See id. at 140-41 (Brennan, J., dissenting).

170 Id. at $141-42$.

171 Id. at 141. 
any similarity between them. And without threads of similarity there can be no tradition. ${ }^{172}$

Engaging a tradition at higher levels of abstraction, as does Justice Brennan, on the other hand, requires extracting similarities that transcend the particular contexts in which they are inscribed. What ties together the traditional conception of the family unit, according to which the father exercises control over his children born in wedlock, and the genetic father and his child in Michael H., is the relation of parent to child shorn of all its specific contextual determinations. By traveling along the metaphoric path, one can seek to distill the essence of a tradition, and thus adapt that tradition to changing circumstances. This process of metaphoric distillation requires decontextualization, and hence ascent to higher levels of abstraction. But as decontextualization becomes more radical, and hence as abstraction reaches the highest levels, metaphoric substitution becomes increasingly unconstrained. As a consequence of this, the metaphoric condensation that reveals the "essence" of a tradition is so removed from any solid contextual moorings as to become arbitrary. Thus, what is the essence of the tradition involved in Michael H.? Is it the protection of the integrity of the family unit? Or, is it the protection of the relationship between parent and child (even beyond the bounds of the traditional family unit)? For those who would opt for the latter, the former could be characterized as a substitute that was appropriate for a time, unlike our own, when paternity could not be established with sufficient scientific probability to avoid uncertainty and disputes concerning who was the real father of a child born to a married woman who had had an affair with a putative genetic father. ${ }^{173}$ On the other hand, for proponents of the position that integrity of the family unit as such constitutes the essence of the relevant tradition, extending parental rights beyond the bounds of that unit cannot count as an acceptable substitute. To reach that conclusion, moreover, these latter proponents must disregard-that is, abstract from - the current proliferation of intimate association arrangements that go beyond the bounds of the historically recognized family unit. Thus, by taking different journeys through the metaphoric path, one can distill different essences from the same tradition, but none of these seems any more compelling than any other.

172 Cf. J.M. Balkin, Tradition, Betrayal and the Politics of Deconstruction, 11 CARDozo L. REv. 1613, 1615-16 (1990) (arguing that Justice Scalia's conception of tradition rests on a set of metaphysical assumptions).

173 This argument was advanced in support of constitutionalizing the genetic father's visitation rights in Michael H. See Michael H. v. Gerald D., 491 U.S. 110 (1989). 
Ultimately, elevating a tradition to the highest possible levels of abstraction is as destructive of tradition as is reducing it to its utmost specificity. Indeed, unconstrained substitution or distillation makes it possible to extract such a broad array of competing meanings from the same tradition as to reduce such tradition to an empty placeholder, to be filled in according to the predilections of its current proponents. Consistent with this, traditions cannot be either exhaustively contextualized or thoroughly abstracted, but must operate at some intermediate level at which contextual factors constrain the process of distilling and adapting the essence of a particular tradition, without blurring the distinction between what is enduring (and hence context-transcending) and what is contextspecific about that tradition. In short, the very notion of tradition requires the selection of suited coordinates along both the metaphoric and the metonymic axes.

Based on the preceding analysis, we are now in a position to grasp how tradition, through overdetermination, occupies a privileged place from which it can tie together the various disparate and even contradictory strands of Due Process liberty rights. On the one hand, tradition binds together the countertradition embedded in constitutionalism with the neotradition required to fashion a positive constitutional identity. Precisely because the American Constitution supplants tradition rather than merely becoming engrafted on tradition, it has a strong need to fill the void left by its repudiation of tradition. This need, in turn, is met in part by symbolizing its countertraditional past as a tradition. Moreover, if this symbolization does not ring false, it is because overdetermination amalgamates two distinct semantic connotations: first, the Constitution is itself the tradition; and, second, whereas the Constitution is in significant measure countertraditional, it nevertheless does not filter out all preexisting traditions, and can thus appropriate for its own use those traditions that do not threaten its integrity. In Freudian terms, tradition thus stands for both repression of traditionby erasing tradition through the display of that which is counter-totradition as tradition-and for the return of the repressed-since the American Constitution is in fact so firmly countertraditional, the return of partial and watered-down practices, even if clothed in the trappings of tradition, fills a lack without undermining the original repression.

On the other hand, the neotradition is also linked to the countertradition and to preexisting (preconstitutional) traditions through overdetermination. In one sense, the neotradition-such 
as, for example, the use of contraceptives within the marital relationship-is no tradition at all. But that does not preclude tracing its pedigree in the countertradition of the Constitution, which has been resymbolized as a tradition in its own right. In another sense, however, the neotradition can be linked back to preexisting traditions through the establishment of suitable metaphoric and metonymic connections between the two. Thus, whereas it may be that the preexisting tradition justifies its latter day derivative-and while it may be important for legitimation purposes that such appearance be widely held true-in fact, it is the neotradition, which partly reincorporates the preexisting tradition, and which appropriates it as transformed for its own purposes. ${ }^{174}$

Determination of suitable coordinates along the metaphoric and metonymic axes for purposes of grounding a tradition to be incorporated into Due Process liberty rights depends on several different factors. First, the tradition in question cannot undermine or threaten the countertradition that sustains the constitutional order. Second, this tradition cannot contravene or weaken structural constraints inherent in constitutionalism. Third, this tradition must be susceptible of plausible (after-the-fact) linkage to a preexisting (preconstitutional) tradition. And fourth, this tradition must be susceptible of wide acceptance as being authoritative among a sizeable majority within the polity. ${ }^{175}$ Consistent with this, moreover, the relevant question in constitutionalizing a tradition is not what level of abstraction is appropriate, but rather whether the contemplated tradition can fully meet the hurdles stemming from the four above mentioned factors. And if a tradition can successfully meet these hurdles at a certain level of abstraction, then that level is the appropriate one.

Overdetermination both links preconstitutional tradition, the countertradition of the constitution and the neotradition necessary

174 In this connection, a comparison of the handling of preexisting tradition in Griswold and in Eisenstadt is quite instructive. In Griswold, the sanctity of marriage was invoked to justify the use of contraceptives. In Eisenstadt, however, it was the individual privacy traditionally protected within marriage that was further abstracted to justify the use of contraceptives among nonmarried consenting adults.

175 Thus, for example, linking the freedom to use contraceptives to the tradition of marital privacy has generated little controversy over the years as use of contraceptives is hardly controversial among a vast majority of Americans. Linking the right to abortion to the traditional freedom to decide whether to bear or beget a child, however, has been much less successful, as the contentious debate over abortion since the Supreme Court's decision in Roe v. Wade, 410 U.S. 113 (1973), plainly attests. Accordingly, the neotradition surrounding the right to abortion has had difficulty being accepted on account of sharp divisions on this issue. 
to construct a positive constitutional identity; and, insures that the uses of tradition to frame constitutional rights are both legitimate and appropriate. Overdetermined tradition is thus not arbitrary, but that does not mean that it must become fixed for all time. Paradoxically, one of the chief virtues of tradition insofar as it frames constitutional Due Process rights, is its open-endedness, malleability, and porousness. Indeed, the very process of overdetermination is sensitive to differences of time and place. Thus, what may satisfy the requirements derived from the four factors listed above under one set of circumstances, may fail to do so under another. A tradition fit for one occasion may not be suited for the next, or at least it may not be suited if taken at the same level of abstraction. In sum, by condensing the process of blending together fragments of preconstitutional traditions, constitutional countertradition, and new elements in need of a pedigree relating back to tradition, into special species of tradition; constitutional identity can evolve and reinvent itself without abdicating its rootedness in some plausible, collective past.

\section{Concluding Remarks: Potential and Limitations of the Constrtutional SubJect's Search For Equildbrium Between Self and Other}

That the identity of the constitutional subject always involves a lack is at once reassuring and worrisome. It is reassuring, in that there is always room for further improvement and greater perfection. It is also worrisome, however, not only because what is openended and forever incomplete is likely to provoke anxiety, but also because efforts to perfect a (necessarily) less than fully elaborated constitutional identity may result in a setback rather than in any improvement. Although Hegel's dialectical logic has proved persuasive in examining the vicissitudes of constitutional reconstructive dynamics, ${ }^{176}$ his confidence in the necessity of progress no longer rings true. ${ }^{177}$ Indeed, as pointed out in the discussion of constitutional equality rights, attempts to advance from second stage equality-as-identity to third stage equality-as-difference, are fraught with the danger of falling back to first stage difference-as-

176 See supra part III.A.

177 See Charles Taylor, Hegel 537-38, 547, 551 (1975) (Hegel's actual synthesis has become obsolete and his belief in the complete overlap of reason and reality seems highly implausible today.). But see Slavo ŽxžeK, The Sublime Object of Iofology 6 (1989) ("far from being a story of [the] progressive overcoming [of antagonism], dialectics is for Hegel a systematic notation of the failure of all such attempts"). 
inequality. ${ }^{178}$ Notwithstanding the danger of losing ground, the constitutional subject cannot stand still, much less remain fixated on the originary myth surrounding the generation of constitution makers. Stunting the evolution of constitutional identity is bound to lead to pathologies, as the obsolete constitutional constructs of yesteryear become more likely to yield repression rather than enhancing possibilities of emancipation.

The evolving identity of the constitutional subject relies, as we have seen, on invention and reinvention of tradition. ${ }^{179}$ This does not mean, however, that constitutional identity can be crafted at will, or that it is bound to remain arbitrary. Which elements of preconstitutional tradition may figure in the reconstruction of constitutional identity, and how they may become integrated with new or transformed elements to make up a plausible neotradition, is subject to determinate structural, functional, and cultural constraints. These constraints rarely, if ever, compel any single outcome, but they significantly curtail the number of available options. Indeed, inevitable competing pressures call for the work of overdetermination, which, in turn, results in a great narrowing of the semantic choices along the interstices of negation, metaphor, and metonymy.

Within these constraints, the identity of the constitutional subject can never become settled, for there is no way to overcome the split between self and other. As gauged from the vantage point of the constitutional subject, moreover, this split is both internal and external. On the one hand, it is internal inasmuch as the constitutional polity is necessarily pluralistic in nature. Such polity may be atomistically pluralistic, with each individual pitted against all others, or made up of a plurality of distinct groups, or both. In any event, the constitutional polity is bound to be internally split, which accounts for its yearning to become enveloped in a commonly shared constitutional identity. On the other hand, the split between self and other is external to the extent that a polity as a whole distinguishes itself from other polities. Furthermore, the external other can play a significant role in shaping the national and constitutional identity of a polity. Thus, not only is national identity likely to be shaped, at least in part, by the rejection of foreign identities, but also constitutional identity may be partially determined by negative incorporation of constitutional norms prevailing

178 See supra part III.

179 See supra part II. 
in another polity ${ }^{180}$ Consistent with this distinction, the self should seek reconciliation with internal others and adopt an inclusionary approach towards them. In contrast, it seems permissible for the self to keep external others at a distance and even, in some cases, adopt an exclusionary attitude towards them. ${ }^{181}$

The divide between internal and external others, however, does not by any means, always track national boundaries. This is undoubtedly due, in part, to the emergence of transnational constitutional or quasi-constitutional norms since the end of the Second World War. ${ }^{182}$ But it is also due, at least as significantly, to the external other often dwelling within the polity. Thus, for instance, African American slaves must be considered as constituting an external other in the context of American constitutional identity, prior to the Civil War. Moreover, as both the internal and the external other can readily move across national boundaries, what is important is above all the generic differences between the two, and the dialectic that links them to one another in the pursuit of constitutional identity.

Focusing upon the broad outlines of the dialectic between internal and external other, sheds useful light on the potential and limitations of the constitutional subject in its quest to strike an equilibrium between self and other. Under the best possible conditions, the division between internal and external other rests on a legitimate basis which is morally defensible. Under such conditions, moreover, the constitutional subject should treat the internal other in an inclusionary manner, while dealing with the external other in an exclusionary way. Finally, inclusionary treatment can

$180 \mathrm{By}$ "negative incorporation" of another country's constitutional norm, I refer to the situation in which country A specifically rejects, after careful consideration, a constitutional norm previously adopted in country B. See JACOBSOHN, supra note 156 , at 12 .

181 There is a tendency to regard exlusionary attitudes as being reprehensible. Upon careful consideration, however, whether a policy of exclusion is to be lauded or condemned depends on the circumstances involved and on whom is being excluded. Thus, exclusion of Nazis or racists from a political organization would seem laudable in almost all cases. Similarly, it seems commendable to seek implantation of a constitutional identity that contrasts with that of a neighboring country which has become prey to an oppressive regime. Moreover, even when the excluded alternative is not inherently undesirable or reprehensible, an exclusionary approach may nonetheless be justifiable. For instance, in choosing between an inclusionary policy making adults responsible for the welfare of all children and an exclusionary policy making parents liable for the well-being of their own children, it is certainly defensible to argue that the exclusionary alternative is preferable in view of the natural bond that exists between parent and child. Accordingly, a greater number of children may well be better off if left to the care of their own parents rather than to the adult population at large.

182 See Louis Henkin, A New Birth of Constitutionalism: Genetic Influences and Genetic Defects, 14 Cardozo L. REv. 533, 537 (1993). 
revolve either around identities or around differences. In the first of these cases, the self includes the internal other on the basis of commonly shared identities - in the sense of similarities-which must be stressed above all differences, thus requiring both self and other to exercise self-censorship and curb that which sets them apart. In the second case, inclusion encompasses recognition and acceptance of differences; which means not merely tolerance of diversity but rather positive encouragement of the pursuit of difference, with a view to maximizing both the self's, and the internal other's, potential for flourishing in an atmosphere of mutual care and respect. Accordingly, all else remaining equal, inclusionary treatment of the internal other honoring differences is preferable. ${ }^{183}$

Even under the best possible conditions, however, full reconciliation between self and internal other is bound to remain out of reach. This means that the identity of the constitutional subject can never be wholly representative of, or equally satisfactory to, all those who come within its sweep. Thus, even in the most multicultural and pluralistic of constitutional polities, not all cultures or religions could be equally accommodated. This is because, as already noted in the above discussion of pluralism, ${ }^{184}$ it is impossible to ascend to a neutral position equidistant to all the differences vying for inclusion within the constitutional subject.

Consistent with these observations, the best equilibrium between self and other that the constitutional subject could hope to achieve, is one in which as many differences as possible are accommodated in the inclusionary gesture towards the internal other. The ideal of integrating all differences, though unreachable, serves a useful critical purpose as a counterfactual meant to remind us that all constitutional identities fall short, and are in constant need of further perfection and completion. Exclusive reliance on this ideal, however, is inadequate when it comes to criticizing a reconstruction of constitutional identity from the standpoint of a preferable, yet attainable alternative. When a constitutional identity falls short of such an alternative, it is that alternative which must provide the counterfactual baseline for critical assessment. Moreover, the availability of such alternatives depends on the possibility,

183 An example of a situation in which stress on difference would seem less desirable than stress on identity would be where, under pressure from an aggressive external other, the internal other is in danger of becoming transformed into yet another external other. Under such circumstances, stress upon differences may exacerbate the danger, whereas stress on identities might minimize it.

184 See supra part II.A. 
within the constraints imposed by constitutionalism, for the self to further accommodate the differences of the internal other without compromising the core elements or the integrity of its conception of the good, as mediated by the fundamental requirements of constitutionalism. Further mutual adjustment is often possible, as conceptions of the good and value preferences are not static, but rather susceptible of transformation in ways that may promote greater overall emancipation without calling for increased overall repression. ${ }^{185}$

The thrust towards greater inclusiveness and greater accommodation of differences, however, is fraught with risks. As the realm of the internal other expands beyond the boundaries of the nation-state, the self may well become more uncertain and more insecure about its identity. And the more one's positive identity appears under assault, the more tempting it may seem to regain control through exclusion. ${ }^{186}$ To prevent that, the counterfactual imagination must rise to the challenge and provide the critical tools necessary to undermine the implantation of unnecessarily repressive constitutional identities.

185 See JÜrgen Habermas, Communication and the Evolution of Society 90 (Thomas McCarthy trans., Beacon Press 1979) (1976) (arguing that needs are not fixed, but rather susceptible of dialogical transformation).

186 Paradoxically, as the realm of the internal other extends farther, the external realm may well move ever closer to home and become perceived as a growing threat within the polity. When this happens, exclusionary identity tends to replace the pursuit of inclusiveness and openness to difference. Taken to its logical extreme, this tendency would be destructive of constitutionalism and of the constitutional subject as the exclusionary self would secure its identity through subordination and oppression of those whom it could cast as being different. But even far short of that, the tendency towards exclusionary identity may rob the constitutional subject of much of its emancipatory potential. 
